NBER WORKING PAPER SERIES

\title{
EARLY CHILDHOOD HEALTH SHOCKS AND ADULT WELLBEING: EVIDENCE FROM WARTIME BRITAIN
}

\author{
Jeffrey C. Schiman \\ Robert Kaestner \\ Anthony T. Lo Sasso \\ Working Paper 23763 \\ http://www.nber.org/papers/w23763 \\ NATIONAL BUREAU OF ECONOMIC RESEARCH \\ 1050 Massachusetts Avenue \\ Cambridge, MA 02138 \\ August 2017, Revised March 2019
}

\begin{abstract}
We thank Greg Brock, Marcus Casey, Jiajia Chen, Don Fullerton, Cuiping Schiman, Ben Ost, Javaeria Qureshi, Rand Ressler and seminar participants at CUNY, U Bergamo, UC Riverside, UIC, and UIUC. The views expressed herein are those of the authors and do not necessarily reflect the views of the National Bureau of Economic Research.
\end{abstract}

NBER working papers are circulated for discussion and comment purposes. They have not been peer-reviewed or been subject to the review by the NBER Board of Directors that accompanies official NBER publications.

(C) 2017 by Jeffrey C. Schiman, Robert Kaestner, and Anthony T. Lo Sasso. All rights reserved. Short sections of text, not to exceed two paragraphs, may be quoted without explicit permission provided that full credit, including $(\subset$ notice, is given to the source. 
Early Childhood Health Shocks and Adult Wellbeing: Evidence from Wartime Britain Jeffrey C. Schiman, Robert Kaestner, and Anthony T. Lo Sasso

NBER Working Paper No. 23763

August 2017, Revised March 2019

JEL No. I15,N3

\begin{abstract}
A growing literature argues that early environments affecting childhood health may influence significantly later-life health and socioeconomic status. In this article, we present new evidence on the relationship between infant mortality and later-life outcomes using variation in infant mortality in England and Wales at the onset of World War II. We exploit the variation in infant mortality across birth cohorts and regions to estimate associations between infant mortality and adult outcomes, such as health, disability, and employment. Our findings suggest that exposure to a higher infant mortality environment is significantly associated with higher likelihood of reporting poor health, a higher likelihood of reporting a disability, a lower probability of employment, and a higher probability of reporting no earned income. We also find that the effects of the infant health environment do not become manifest until after age 55 .

Jeffrey C. Schiman

Georgia Southern University

Department of Economics

Statesboro, GA 30458

jschiman@georgiasouthern.edu

Robert Kaestner

Harris School of Public Policy

University of Chicago

1307 East 60th Street (Room 3057)

Chicago, IL 60637

and Institute of Government and Public Affairs

and also NBER

kaestner@uchicago.edu

Anthony T. Lo Sasso

Health Policy and Administration Division

School of Public Health

University of Illinois at Chicago

$1603 \mathrm{~W}$. Taylor

Chicago, IL 60612

losasso@uic.edu
\end{abstract}




\section{Introduction}

A growing literature argues that early environments affecting childhood health may influence significantly adult health and socioeconomic status (Almond and Currie 2011). If so, then investments in early childhood health may have particularly large returns and public policy targeted at infant and child health should be encouraged, particularly when private investment is constrained, for example, among low-income families. In addition, if childhood health does have a lasting effect, then associations between adult socioeconomic status and adult health may overstate the importance of socioeconomic status because child health may have influenced both these adult outcomes.

Infancy may be a particularly important time in life when the health environment could matter for later outcomes, and several studies have assessed this hypothesis using infant mortality to measure the health environment. Barker and Osmond (1986) and Ben-Shlomo and Smith (1991) obtained associations between infant mortality and adult cause of death for birth cohorts born in England and Wales in the late $19^{\text {th }}$ and early $20^{\text {th }}$ centuries. Although both studies found some evidence that higher rates of infant mortality were associated with higher rates of death, particularly from heart disease, associations were not consistent and adjusting for socioeconomic status eliminated significant associations (Ben-Shlomo and Smith 1991). Similar studies using $19^{\text {th }}$ century birth cohorts from countries other than England and Wales generally found evidence of scarring — birth cohorts that experienced relatively high rates of infant mortality experienced relatively high rates of adult mortality (Bengtsson and Lindstrom 2000; Catalano and Bruckner 2006; Crimmins and Finch 2006; Bengtsson and Broström 2009; Myrskylä 2010; Schellekens and van Poppel 2016). Studies of more recent birth cohorts by Bozzoli et al. (2009) and Case and Paxson (2009) reported similar findings. Case and Paxson 
(2009) reported that infant mortality was positively associated with infectious disease and cognitive decline in adulthood, and Bozzoli et al. (2009) found that infant (post-natal) mortality was negatively associated with adult height. A limitation of the studies just described is that they do not exploit plausibly exogenous variation in early-life conditions. ${ }^{1}$ Therefore, it is unclear whether the associations obtained are causal. In addition, most of these studies examining the lasting impact of child health used samples of people born in the late $19^{\text {th }}$ and early $20^{\text {th }}$ centuries and results may not generalize to birth cohorts alive today.

There are several studies that exploit more plausibly exogenous variation in early life (i.e., in utero or infancy) health conditions, for example, Almond (2006) who studied the 1918 flu pandemic, and Bleakley $(2007,2010)$ and Lucas $(2010)$ who studied eradicating malaria and hookworm. ${ }^{2}$ These studies, and many quasi-experimental studies focused on famines, generally find evidence that early life health shocks are associated with worse adult health and socioeconomic status, which is consistent with a scarring effect of early life health conditions. ${ }^{3}$ However, findings from these quasi-experimental studies are not uniform, as a few studies reported no significant association between early health shocks and adult outcomes (e.g., Stanner et al. 1997; and Kannisto et al. 1997; Lumey et al. 2011; Brown and Thomas 2013). Similarly, van Ewijk and Lindeboom (2017) found largely null effects for prenatal cohorts exposed to the adverse effects of World War II in France, Belgium, and the Netherlands.

\footnotetext{
${ }^{1}$ Some of these studies adjust for trends in mortality by birth cohort (Bengtsson and Lindstrom 2000; Myrskylä 2010).

2 There are several quasi-experimental studies that examine not health shocks, but the effect of early economic environments on adult outcomes (e.g., Van de Berg et al. (2006); Cutler et al. (2007); Banerjee et al. (2010); Almond, Currie, and Herrmann (2012)).

${ }^{3}$ See: Roseboom et al. (2001), Almond and Mazumder (2005), Almond (2006), Almond et al. (2007), Chen and Zhou (2007); Lindboom et al. (2010); Neelson and Stratmann (2011); Kelly (2011), Almond et al. (2012), Bharadwaj et al. (2013), Dinkelman (2017), and Hjort, Sølvsten, and Wüst (Forthcoming).
} 
We present new evidence on the relationship between infant health and later-life outcomes using plausibly exogenous variation in infant mortality in England at the onset of World War II. Our research makes several contributions to the literature. First, we focus on relatively recent birth cohorts. As noted, many studies have used $19^{\text {th }}$ century birth cohorts. Second, we exploit plausibly exogenous variation in infant mortality. Third, as we explain in more detail below, we assess whether the health environment in infancy is particularly important vis-à-vis the health environment at other ages during childhood. Fourth, we examine whether fertility responses confound the effect of the infant health shock. ${ }^{4}$ Finally, we assess whether effects of adverse infant health environment differ by family socioeconomic status and whether effects, if any, manifest at different ages over the life course.

The key empirical fact that motivates our study is the spike in infant mortality (deaths under 1 year of age per 1,000 births) in England in 1940 and 1941; infant mortality rose 17 percent between 1939 and 1941, although the increase is even larger than this value implies because infant mortality was declining steadily during this period. The increase in infant mortality was largely driven by a marked increase in post-neonatal deaths mainly from pneumonia and whooping cough. Historical evidence indicates that the rise in infant mortality during this period was due to a combination of a wartime food rationing, disease transmission in day nurseries, and unusually harsh winters (discussed in the following section). From 1942

\footnotetext{
${ }^{4}$ Our research is somewhat related to studies that have examined the long-term impact of childhood exposure to warfare and armed conflict on adult outcomes (e.g., Akresh et al. (2012); Akbulut-Yuksel (2014); Kesternich et al. (2014); Lee (2014); and Havari and Peracchi (2017)). Kesternich et al. (2014) and Havari and Peracchi (2017) study the effect of WWII on several European countries, although not England, and they define exposure in terms of ground combat. However, these studies examined exposure to general war conditions including, poor nutrition, mass dislocation, combat and destruction of the physical environment. Our study is different because we do not study the effects of warfare, but the war-induced rise in infant mortality in 1940-41, which is a very specific exposure caused by identifiable factors. Ground combat never occurred in the United Kingdom, and bombing and relocation was focused mainly on London and a few port cities. The German bombing of London began at the end of 1940 subsequent to the initial spike in infant mortality observed in the data (see Figure 1). We describe the nature of the exposure and the quasi-experimental design in more detail below.
} 
onward, infant mortality fell back to its pre-1940 trend arguably because of priority rationing that favored pregnant women, less harsh winters, and improvement in health services in childcare facilities (see Figure 1).

Within England, the extent to which infant mortality increased varied markedly across regions. For example, infant mortality in London changed little between 1939 and 1941 while in Northeast England it rose by nearly 27 percent. Because the negative health shock was short lived, severe, and varied within the country, it provides a natural opportunity to test the relationship between exposure to an adverse, early childhood health environment and later-life outcomes.

Using data from the British Household Panel Survey, we exploit the variation in infant mortality across districts and cohorts of birth to estimate associations between exposure to a higher infant mortality environment and adult outcomes, such as presence of various health conditions, employment, earned income, education, home ownership, and disability. Our findings suggest that the increase in infant mortality in the early 1940s is associated with worse health as an adult. Specifically, a one standard deviation increase in infant mortality is associated with approximately a $24 \%$ increase in reporting poor/very poor health; a $35 \%$ increase in reporting a disability; a $10 \%$ decrease in the probability of having a job at the time of the survey; a 17\% increase in reporting no annual real income; and a $9 \%$ decrease in reporting top tercile annual real income. Notably, these associations manifest mainly in later life, particularly after age 55. Another important finding of our study is that childhood socioeconomic status, as measured by father's occupation, does not appear to have moderated the adverse association between infant mortality and adult outcomes. 


\section{Background: England and Wales in the 1940s}

Since the 1930s, infant mortality in England followed a marked downward trend except for 1940 and 1941, as shown in Figure 1. Between 1939 and 1942, infant deaths rose from 50 per thousand births in 1939 to 59 per thousand births in 1941 and the dropped back to 49 per thousand births in 1942. The deviation from trend in 1940 and 1941 is arguably the result of the interaction of food rationing policies, crowding and poor conditions in day nurseries, and the unusually harsh winters of 1940 and 1941, each of which we discuss in turn.

The Ministry of Food was created in 1939 and was responsible for food distribution during the war. Various rationing schemes were used including direct distribution of items and allocations based on coupons and points for different foodstuffs. Food items including milk, eggs, cereals, oranges, butter, bacon, sugar, meats, and cheeses were rationed beginning in January of 1940 at the start of major wartime actions and rationing became increasingly stringent as the war went on. The allocated rations provided approximately 910 calories per day, but little calcium and vitamins. Orr (1937) reported that, depending on family income, per-capita calorie consumption was between 2300 and 3330 in 1932-35. Therefore, the rationing of food and provision of 910 calories per day suggests that nutrition was likely to be adversely affected by the war, although we do not know what actual caloric intake was during the war. While many food items were included in the ration, some were not-for example, bread was not rationed.

To protect the health of women with children and expectant mothers, the National Milk Scheme was implemented in June of 1940 and provided additional priority allowances, which supplied an additional 540 calories per day and the bulk of their daily requirement of calcium and vitamins. However, initial take-up was low and the program did not witness significant uptake until 1942. The priority allowance was later credited as having "done more than any other 
single factor to promote the health of expectant mothers and young children during the war" (Great Britain Ministry of Health 1946, p. 93). Note that infants who died in 1940 were born between January 1939 and December 1940, and were therefore conceived between March 1938 and March 1940. Thus, it is unlikely the food restrictions, which began in January of 1940, influenced nutritional conditions in the womb, instead influencing nutritional conditions after birth.

By 1940, England began to develop day nurseries for displaced children and children of parents engaged in the war effort (Great Britain Ministry of Health 1946, p. 98). Initially, staying in the day nurseries was associated with the transmission of infectious disease given close confinement of children and disorganization as local authorities worked to "extend water supplies, sewerage and drainage, and to increase hospital accommodations for maternity and infectious disease, and to obtain many more midwives" in areas that previously lacked these amenities (Great Britain ministry of Health 1946, pg 107). However, by 1942 the quality of the nurseries improved because of better staffing and more abundant supplies and resulted in a decrease in the incidence of disease (Great Britain Ministry of Health 1946, p. 99). Note that during this period (e.g., 1940), England was under assault from bombing campaigns that targeted the more densely populated and better developed areas of England such as London. From these areas, the government evacuated children and expectant mothers to rural areas in England (Great Britain Ministry of Health 1946, 92). The number of local and evacuated children being cared for in day nurseries likely exacerbated shortages in supplies, staff, and accommodations that arguably further adversely affected the quality of infant and child healthcare, further raising infant mortality rates. In addition, the evacuation may have been non-random with respect to 
income and child health, for example, poorer families may have been over represented, and this would alter (e.g., raise) disease in places where children were evacuated.

Another adverse event at the time was weather. The 1940 and 1941 winters produced extremely low temperatures, extensive frosts, and large snows. The meteorological record from the period described January 1940 as "exceptionally cold; intense frost; considerable snow in the latter half of the month"; January 1941 was described as "cold, with frequent snow" ("Monthly Weather Reports 1940s" 2016). The inclement weather of the period was not uniform across regions, however, as England, despite being a relatively small country, has surprisingly diverse microclimates that exacerbate or buffer general weather patterns. For example, within Devon County in the Southwest of England, the average monthly temperature can vary by 4 degrees Celsius within a 20 mile radius and rainfall can be twice as much in one area as another. ${ }^{5}$

The evidence from rationing and harsh winters is consistent with areas farther from London experiencing a greater increase in infant mortality. More remote areas likely had fewer resources and fewer rationed goods. Historical weather information suggests that the winters in the north of England were somewhat harsher than in the south, which also partly explains the within-country variation. Appendix Figure 1 presents the difference in average January temperatures between the observed value and a region-specific linear trend. The figure illustrates that the 1940/41 winters were particularly harsh across the UK, with the regions experiencing January temperatures around three to six degrees below trend. Note that in the years leading up to $1940-41$, the temperature across regions follows a similar trend, suggesting no pre-existing differences in weather trends. Moreover, the predominately rural areas where shelters were built

\footnotetext{
${ }^{5}$ See Appendix Figure 1 and http://www.metoffice.gov.uk/binaries/content/assets/mohippo/pdf/n/9/fact_sheet_no._14.pdf (last accessed 7 August 2017)
} 
to house expectant mothers were also away from London, which would additionally explain part of the pattern in infant mortality.

To explore further the relationship between weather and infant mortality, we compiled weather data from the UK meteorological office. ${ }^{6}$ The data contain monthly measures of average minimum temperatures which we use to illustrate the relationship between infant mortality and weather in Figure 2. The solid line represents deviations from a linear trend in infant mortality from 1931 to 1960 . The dashed line represents deviations from a linear trend in the average minimum daily temperature in January of each year. The two measures appear inversely correlated, with mortality rising above trend when minimum temperatures fall below. Particularly salient is the sharp decline in minimum temperatures during 1940 and 1941, which coincide with sharp increases in mortality. Note too, that the increase in infant mortality coinciding with the colder winters in 1940-41 is significantly larger than the increase in infant mortality corresponding to similarly a cold winter in 1945, which is consistent with the interaction between poor nutrition, poor conditions in day nurseries, and cold weather. Although we lack weather data on all areas of the UK, the analysis is suggestive of unusually harsh winter conditions in 1940-41.

Table 1 displays infant mortality rates by cause between 1939 and 1942 . The noteworthy contributions to the increase in mortality in 1940 and 1941 are bronchitis, pneumonia, and whooping cough. These illnesses account for $60 \%$ of the total increase in infant mortality between 1939 and 1941, and are conditions that are plausibly affected by inadequate nutrition, inclement weather, and wartime dislocation. For example, harsh winters, poor nutrition combined with a lack of fuel products to heat homes (from the ration), and the crowding of

\footnotetext{
${ }^{6}$ http://www.metoffice.gov.uk/public/weather/climate-historic/\#?tab=climateHistoric (last accessed 7 August 2017). Only six of our ten regions are represented during the entire 1930 to 1960 timeframe.
} 
children into day nurseries may have facilitated the transmission of pneumonia and whooping cough because of their infectious nature (Griffiths and Brock 2003). Indeed, infancy exposure to whooping cough has also been shown to affect later life outcomes in Sweden (Quaranta 2014). Moreover, several researchers have linked pneumonia incidence to vitamin D deficiency (Muhe et al. 1997; Wayse et al. 2004; McNally et al. 2009; Wonodi et al. 2012). Eggs are rich in vitamin $\mathrm{D}$ and were among the rationed food items that were particularly scarce in the early war years.

Figure 3 displays the aggregate trend in neonatal, post-neonatal, and childhood mortality in England and Wales from the period. Note that while overall neonatal mortality increases somewhat, the significant deviation from trend occurs for post-neonatal mortality and mortality for children aged 1-2 and aged 3-5. Notably, we also observe substantial variation in the magnitude of infant deaths within the United Kingdom across regions and districts. The United Kingdom is divided into regions, which are comprised of counties, and counties comprised of districts. Generally, areas farthest from London experienced the greatest rise in infant mortality.

In Figure 4 we present the difference in infant mortality between observed value and a predicted linear trend by region. A value of zero indicates that infant mortality in a region is perfectly on trend. In 1940-41, there is a clear upward divergence from trend with regions farthest from London experiencing the largest increases. ${ }^{7}$

To summarize, Figures 1-4 and Table 1 document the circumstances surrounding the significant spike in post-neonatal and early childhood mortality in 1940-41. The combination of

\footnotetext{
${ }^{7}$ We also conducted a regression analysis using infant mortality in district $\mathrm{d}$ in region $\mathrm{r}$ for cohort $\mathrm{c}$ as the dependent variable with controls for region fixed effects, cohort fixed effects, and region-by-cohort fixed effects. Results of this analysis indicated that all pre-1940-41 region-year coefficients were statistically zero. This provides evidence that there were no significant or economically important differences in pre-existing differences in infant-mortality between regions that would confound our estimates.
} 
food shortages, harsh weather, and disruption in children's healthcare resulted in greater incidence of infectious and respiratory disease for young children in 1940 and 1941. Additionally, the incidence differed substantially by region within England. The variation in child health across both time and region, as measured by infant mortality, represents our measure of the exposure to adverse health shocks. These infant health shocks mainly reflect infectious disease, and, as Crimmins and Finch (2006) and others have articulated, there are plausible biological mechanisms linking infectious disease during infancy/childhood to adult disease.

\section{Data}

To test whether exposure to a health shock in infancy affects adult outcomes, we use data from the British Household Panel Survey (BHPS) and the Great Britain Historical Database: Health and Health Care Data Mortality Statistics from 1851-1973. The BHPS is a longitudinal survey of approximately 5,500 households in Britain from 1991 to $2009 .{ }^{8}$ The survey is well suited for our study because respondents are asked their date and place of birth, which we match with the Great Britain Historical Database by district and birth year to determine exposure to the health shock as an infant. The Great Britain Historical Database contains information on infant deaths and births, as well as population by location and year. ${ }^{9}$

The primary sample we use is limited to those born between 1935 and 1950, which is a period that spans the sharp rise in infant mortality, but is a relatively narrow window of time to reduce potential confounding from economic and technological changes occurring during the period. There are 52,348 person-by-wave observations for this sample. From the initial 52,348

\footnotetext{
${ }^{8}$ See (University of Essex. Institute for Social and Economic Research. 2010)

${ }^{9}$ For additional information on the Great Britain Historical Database, see https://discover.ukdataservice.ac.uk/Catalogue/?sn=4570\&type=Data\%20catalogue (last accessed 25 February 2019)
} 
person-waves selected, we drop six observations missing birth month, and 4,784 observations that are missing information for place of birth, and another 12,874 observations for which we are unable to match district-level mortality. Our final sample consists of 34,684 person-by-wave observations for 3,218 persons from 245 districts. In Appendix Table 1, we report descriptive statistics for the sample at each stage of construction, illustrating that the final analysis sample is similar to the initial sample.

The BHPS are longitudinal data covering an 18-year period. In our sample, the average individual is observed in approximately 9.45 waves of the survey. Our primary regression approach uses all person-wave observations thereby treating each person-wave observation as a separate observation. This is a reasonable approach because most outcomes we measure are changing over time as the person ages.

The Great Britain Historical Database reports district-level annual infant mortality during this time period. We use annual mortality in conjunction with the BHPS, which reports individual birth month, to calculate infant mortality $(I M)$ and birth rates by district and year. ${ }^{10}$ Infant mortality for person $i$ born in district $d$ in year $c\left(I M_{i d c}\right)$ is measured as a weighted average of infant mortality in the year of birth and in the following year, for example, because those born in January experience a different environment than those born in December of the same year. Specifically:

$$
I M_{i d c}=\alpha I M_{i d c}+(1-\alpha) I M_{i d, c+1}
$$

where birth-year mortality $\left(I M_{i d c}\right)$ and the following-year mortality $\left(I M_{i d, c+1}\right)$ are weighted $(\alpha)$ by birth month. An individual born in January receives a weight of 1 . The weight reduces by

\footnotetext{
${ }^{10}$ Specifically, we use table "mort_lgd" which records "Birth \& Death Statistics for Local Government Districts from 1921-1974."
} 
1/12 for each additional month so that an individual born in February receives a weight of $\alpha=$ 0.916; March a weight of $\alpha=0.833$; and so on. The approach places more weight on actual birth-year infant mortality for those born earlier in the year; for those born later in the year more weight is placed on the subsequent year's mortality. $I M_{i d c}$ is our measure of treatment, or exposure, to adverse early health conditions. We standardize infant mortality to have an overall mean of 0 and standard deviation of 1 . The standard deviation of infant mortality is 13.5 , roughly the size of the mortality shock in 1940/41.

Survey respondents in the BHPS answer questions about their health including selfreported health status, presence of health problems, and disability status in addition to information about employment, income, and home ownership. For self-reported health status, individuals are asked, "Please think back over the last 12 months about how your health has been. Compared to people of your own age, would you say that your health has on the whole been" and they may check excellent, good, fair, poor, or very poor from which we define two indicators: an indicator for good or excellent health and an indicator for poor or very poor health. For the presence of health problems, individuals are asked "Do you have any of the health problems or disabilities listed on this card?" which include thirteen conditions including problems with arms or legs, problems with chest or breathing, problems with heart or blood pressure, difficulty seeing, difficulty hearing, skin conditions, stomach/liver/kidney, diabetes, nerves/anxiety/depression, alcohol/drugs, epilepsy, migraine/chronic headache, or other. Respondents could check any conditions that apply and our measure of any self-reported health problems is an indicator that equals one for those who suffer from at least one of the aforementioned conditions. We also examine the top three most prevalent conditions 
individually. ${ }^{11}$ Note that self-reported health measures have been shown to be reasonably strong predictors of mortality (see for example: Franks, Gold, and Riscella 2003 and Idler and Benyamini 1997).

Our measure of disability status comes from the question "Can I check, are you registered as a disabled person, either with Social Services or with a green card?" Those who check yes are defined as disabled. Home ownership status is derived from a question that asks individuals if they own a home or rent a home. We define an indicator for home ownership equal to one if the individual responds that they own their home outright or with a mortgage and zero otherwise. We measure employment using a dichotomous measure that equals one if the respondent did any paid work in the previous week and zero otherwise. Finally, respondents report annual income from labor (i.e., earned income), which we use to create terciles of earned income. The terciles correspond to no earned income, income greater than $£ 0$ and less than or equal to $£ 12954$, and income above £12954. We also report estimates using annual real earnings as a continuous measure instead of the terciles. Respondents are also asked to note the highest level of education they had completed, using the International Standard Classification of Education (ISCED) definitions. We use these reports to generate an indicator for completing primary education only $(\operatorname{ISCED}=1) .^{12}$

Respondents are also asked "Thinking back to when you were 14, what job was your father doing at that time?" If working and not deceased, the father's job title, nature of work, and industry were recorded and used to create several variables that measures the social class of the

\footnotetext{
${ }^{11}$ Approximately $69 \%$ of our sample report suffering from one or more of the thirteen conditions. The top three reported conditions include arm/leg problems (38\%), heart/BP problems (23\%), and chest or breathing problems $(13 \%)$.

${ }^{12}$ Because education does not change during the ages of life we observe, analyses of this outcome use a randomly selected observation for each person instead of all the years a person was observed.
} 
father's job. Occupations are grouped into the following categories: professional, managerial/technical, skilled (manual/non-manual), partly-skilled, and unskilled. From this we categorize respondents as growing up in a high (professional or managerial/technical) or low (remaining categories plus non-working/deceased) socioeconomic class.

Table 2 reports descriptive statistics. On average, the sample is 56 years of age, although there is significant variation in age indicated by a standard deviation of 6.8 years. Slightly more of the sample is female (54\%), which is consistent with longer life expectancy of females vis-àvis males. Figures related to our outcomes indicate that approximately $69 \%$ report a health problem, although only $12 \%$ report being in poor or very poor health. The apparent discrepancy between the proportion being in poor health and the proportion with a health problem likely reflects the self-reported nature of the questions and the fact that many respondents report a health problem that is relatively minor. Roughly $37 \%$ report having no real earned income. Those in the final analysis sample have similar characteristics to the full BHPS sample, as illustrated in Appendix Table 1.

\section{Measurement of Exposure}

Our measure of exposure, or treatment, is the infant mortality in the district and year of birth, which is derived from administrative data. Given the wartime relocations, there is a question as to whether births and deaths were recorded consistently with respect to place of residence or place of occurrence. The administrative data indicate that deaths were recorded based on place of occurrence. However, it is possible that births might have been recorded at place of permanent residence if relocation occurred soon after birth, but there were great efforts to relocate pregnant women which would minimize this possibility. For example, in 1939, 13,900 pregnant women were relocated out of greater London (Johnson 1985). Consistent with 
this, births in London fell by roughly 20,000 between 1939 and 1941 (Appendix Figure 2).

Therefore, it is likely that most births were recorded in the place of occurrence and thus the extent of any misreporting of births would appear to be small.

A second concern is measuring exposure for individuals who were relocated. Note that the adverse health shocks were manifest within the first year of life, as shown in Figure 3. Thus, infant mortality in the place of birth accurately reflects exposure for all those who stayed in the relocation region for several months, which is likely to be the vast majority of persons that were relocated. ${ }^{13}$ Exposure would be incorrectly assigned if survey respondents who had been relocated reported their birth region as their permanent residence rather than the actual region of birth. To address this concern, given that most of the relocation is associated with London, we re-estimate our regressions omitting survey respondents born in London. Our findings are largely unchanged when we omit London births.

\section{Empirical Approach}

The hypothesis we are interested in assessing is whether exposure to a health shock in infancy affects adult outcomes. This hypothesis is motivated by two broad causal mechanisms. The first is often referred to as "scarring" (Elo and Preston 1992). The scarring channel suggests that exposure to a negative health shock may adversely affect developing organs and the immune system (e.g., inflammation) and cause worse later-life health. For example, the observed increase in infectious disease during 1940-41 because of food rationing and harsh winters may lead to worse later-life outcomes for those born during this period. A second mechanism linking early and late health is often referred to as culling (Almond and Currie 2011). The culling channel

\footnotetext{
${ }^{13}$ However, for those who return to their permanent residence, some of the effect of exposure could be confounded with their moving during childhood.
} 
suggests that during exposure to an adverse health event the weakest children die leaving a healthier group of children. In this case, early health shocks result in better adult health.

Of course, these broad causal pathways are not mutually exclusive and which channel dominates is an empirical question. There may also be behavioral responses to the health shock in childhood. Parents may respond by investing in affected children and, as we discuss below, fertility may be affected by the health shock. Parental responses and their influence are additional considerations relevant to the interpretation of estimates of the association between child health and adult outcomes. Such behavioral responses may reinforce or offset the scarring and culling effects.

\section{Regression Model Specification}

To estimate the effect of infant mortality on later-life outcomes, we use regression methods and the following regression model:

$$
\text { (1) } Y_{i d c m a}=\alpha+\beta I M_{i d c}+\gamma X_{i a}+\theta_{d}+\phi_{c}+\delta_{m}+\lambda_{a}+\varepsilon_{i d c m a}
$$

$i=$ (individuals)

$d=1,2, \ldots, 245$ (Districts)

$c=1935, \ldots ., 1950$ (Birth year cohort)

$m=1, \ldots, 12$ (Birth month)

$a=40, \ldots, 73$ (Survey Age)

where adult outcome $Y_{i d c m a}$ for individual $i$ born in district $d$ in birth year $c$ and month $m$ and surveyed at age $a$ is a function of the weighted-average infant mortality rate (per one thousand live births) in their district and year of birth, $I M_{i d c}$. Other covariates include controls for observable individual characteristics at the time of survey $\left(X_{i a}\right)$ including current place of residence and sex, a district of birth fixed effect $\left(\theta_{d}\right)$, a birth cohort fixed effect $\left(\phi_{c}\right)$, a birth month effect $\left(\delta_{m}\right)$, a survey age fixed effect $\left(\lambda_{a}\right)$, and an error term $\left(\varepsilon_{\text {ircma }}\right)$. The adult outcomes we consider are self-reported health status, incidence of health problems, disability status, 
educational attainment, labor force participation, real annual labor income, and home ownership. ${ }^{14}$

The district fixed effect $\left(\theta_{d}\right)$ accounts for unobserved differences between the districts including resources available, local economic conditions, local development, and any other fixed differences across districts related to both infant mortality and later-life outcomes for the cohorts born between 1935 and 1950. By including the fixed effect, we compare outcomes for those born within the same districts. The birth cohort fixed effect $\left(\phi_{c}\right)$ accounts for differences by year of birth common to all individuals in England and Wales, such as changing medical technology, environmental conditions, or aggregate trends in the UK economy that account, partly, for the downward trend in infant mortality experienced during this time. The survey age fixed effect $\left(\lambda_{a}\right)$ accounts for any differences in age at the time of the survey (and any survey year effects because birth year plus age equals survey year).

The identifying assumption of our approach is that, conditional on district, age, and birth year fixed effects, variation in infant mortality is largely driven by exogenous factors associated with the war such as food rationing and adverse weather conditions. To test for the presence of pre-trends in the outcome variables, we conducted a regression analysis using each outcome as the dependent variable with controls for region fixed effects, cohort fixed effects, and region-bycohort fixed effects. We omit London as the base region and 1935 as the base cohort. Results of this analysis indicated that pre-1940-41 region-year coefficients were statistically zero. This provides evidence that there were no significant or economically important differences in preexisting differences in outcomes between regions that would confound our estimates. The results

\footnotetext{
${ }^{14}$ We adjust annual labor income for inflation using the CPI index available here https://www.ons.gov.uk/economy/inflationandpriceindices/timeseries/d7bt/mm23 (accessed 21 December 2016). We use 2008 as the base year.
} 
of this analysis are available in Appendix Figure 3. In some specifications, we include districtspecific, linear birth-year trends and the results remain unchanged. ${ }^{15}$ To estimate equation (1), we use a linear probability model for dichotomous outcomes, but estimated effects are similar when using a logit model. The effect of infant mortality as embodied in the coefficient $\beta$ represents the consequences of an adverse health shock early in life.

As noted earlier in the description of the data, the sample includes multiple observations for each person, which raises three potential concerns: one related to the construction of standard errors; another related to the timing of any effect (or age that an effect becomes manifest); and a third related to possible bias from including different numbers of observations for individuals if, for example, survival is correlated with infant mortality.

With respect to standard errors, we use a cluster-robust method that assumes the errors are correlated (non-independent) within district of birth cells (i.e., the level of treatment). While we believe this method is valid even in the context of multiple observations per person, we also used an alternative method that clusters standard errors by person, thus assuming nonindependence of errors within a person over time. Standard errors from this alternative approach were very similar to those we reported and are available in Appendix Table 2.

With respect to the possibility that using more observations for some individuals and fewer for others may introduce bias, we obtained estimates using a sample consisting of one randomly selected observation for each person. In this case, each individual contributes only one observation and the sample of unique persons has the same distribution of characteristics as the full sample that includes multiple observations per person. Estimates from this sample address

\footnotetext{
${ }^{15}$ In a separate specification (available upon request) we also included a survey year linear trend, which had virtually no effect on our estimates. Following Almond and Mazumder (2005), we also interacted age and survey wave which also had virtually no effect on our estimates (available upon request).
} 
concerns over the standard errors and concerns related to any potential issue arising from using more observations for some people than others. This sample is also appropriate when examining education because education does not vary over the ages observed.

\section{Moderation by Socioeconomic Status}

It is possible that family socioeconomic status during childhood could moderate effects of early-life health shocks. For instance, even with a food ration in place, wealthier families may be able to obtain more food through alternative channels, which would tend to lessen any adverse effect. To explore this possibility, we estimate a model that allows the effect of infant mortality to differ by socioeconomic status, as measured by indicators for whether your father worked in a lower (unskilled, partly-skilled, or skilled manual/non-manual) or higher (managerial/technical or professional) social class occupation when you were 14. Specifically, we estimate:

$\theta_{d}+\phi_{c}+\delta_{m}+\lambda_{a}+\varepsilon_{i d c m a}$

Equation (2) is identical to equation (1) except now we include an interaction between infant mortality $\left(I M_{i d c}\right)$ and higher $\left(H I G H_{i d c}\right)$ and lower $\left(L O W_{i d c}\right)$ early-life socioeconomic status. We include both interactions between infant mortality and socioeconomic status and exclude the infant mortality main effect. If differences by early-life socioeconomic status exist, they would be reflected in differences between $\beta_{1}$ and $\beta_{2}$ in equation (2).

\section{Age when Effects Become Manifest}

To investigate the timing (age of occurrence) of observed effects, if any, we estimate a model that allows the effect of infant mortality to differ by age. Specifically, we estimate:

$$
Y_{i d c m a}=\alpha+\beta_{1}\left(I M_{i d c} * A G E_{1}\right)+\beta_{2}\left(I M_{i d c} * A G E_{2}\right)+\beta_{3}\left(I M_{i d c} * A G E_{3}\right)+\gamma X_{i a}+
$$

$\theta_{d}+\phi_{c}+\delta_{m}+\lambda_{a}+\varepsilon_{i d c m a}$ 
Equation (3) is also identical to equation (1) except now we allow the effect of infant mortality to differ by age classified by terciles [the $1^{\text {st }}$ (lowest) tercile ranges from 40 to 53; the 2 nd tercile ranges from 54 to 59; the 3rd (highest) tercile ranges from 60 to 73]. We include all three interactions between infant mortality and age groups and exclude the infant mortality main effect.

\section{Considering Birth Rates}

One issue that merits consideration is the potential response of births to infant mortality. ${ }^{16}$ For example, parents may try to replace children lost to illness (Ben-Porath 1976). Wartime in the UK brought considerable changes in birth rates. Total births in London fell along with the population, but rebounded beginning in 1942 (available in Appendix Figure 2). A similar pattern is evident from the regions outside London. Also, note that London makes up a relatively small fraction (15\%) of total births. We also document birth rates for the entire country (Appendix Figure 4), which indicates that the birth rate started increasing beginning in 1942, eventually peaking in the immediate post-war years. Birth rates from 1935-41 were stable at around 15 per 1,000 total population, but in 1942 birth rates increased to 17 per 1,000 total population. From 1942 until well after the end of the war, birth rates stay at or above this elevated level with some noticeable decline after 1947.

The increase in birth rates in 1942 is suggestive of a parental response to the negative health shock that may vary at the region-by-time level and would not be accounted for by any of the fixed effects in the regression specification. In short, the fertility response may have altered later-life outcomes because of differences in family size (spacing) by birth cohort and district. Therefore, we estimate some models with birth rates to assess whether estimates of the

\footnotetext{
${ }^{16}$ There may be other (parental) responses, but we are unable to measure them because of data limitations.
} 
association between infant mortality and later-life outcomes is sensitive to the inclusion of birth rates.

\section{Results}

Table 3 presents estimates of the association between infant mortality in the respondent's region and year of birth and adult outcomes. ${ }^{17}$ In all regressions, infant mortality is standardized to have an overall mean of 0 and standard deviation of 1 and standard errors are clustered by district of birth cells. The first column of Table 3 shows the baseline specification without additional person-level covariates or controls for birth rates. The second column adds personlevel controls including age, sex, and current region of residence. The third column adds the birth rate in the year and district the respondent was born. The fourth column adds district-specific, linear birth-year trends.

Estimates for each outcome are similar across the four columns. The estimates suggest an adverse effect of a poor infant health environment on adult health and socioeconomic status, which is consistent with a scarring effect. For instance, the association between infant mortality and self-reported poor/very poor health suggests that a one standard deviation increase in infant mortality (roughly the size of the increase between 1939 and 1941) is associated with approximately a 2.9 percentage point increase in poor/very health, which is a $24 \%$ increase relative to the mean. With respect to self-reported disability, the estimates suggest that a one standard deviation increase in infant mortality (roughly the size of the increase between 1939 and 1941 ) is associated with approximately a 3.5 percentage point increase in disability, which is a $35 \%$ increase relative to the mean. The estimate remains stable across all specifications. A

\footnotetext{
${ }^{17}$ We also estimated a non-linear specification where infant mortality entered as a quadratic form (available upon request), but the results do not differ qualitatively from the linear specification.
} 
summary of the other significant effects of a one standard deviation increase in infant mortality is as follows: ${ }^{18}$

- An approximately 5.7 percentage point $(10 \%)$ decrease in the probability of having a job;

- an approximately 6.4 percentage point increase $(17 \%)$ in the probability of reporting no earned income;

- and an approximately 3 percentage point decrease ( $9 \%)$ in the probability of reporting earned real income above $£ 12954$ (the $3^{\text {rd }}$ and highest real income tercile) .

Notably, estimates in column 4, which come from regression models with district-specific, linear birth-year trends are largely similar to estimates in other columns. The specification of the model in column 4 controls for potentially unmeasured confounding from factors that vary by district and birth year. Therefore, the similarity of estimates across columns suggests that the variation in infant mortality arises largely exogenously due to food rationing, weather and conditions in day nurseries described earlier.

In Table 4, we explore whether the effects of infant mortality differ by father's occupational (socioeconomic) status. In particular, we estimate equation (2) which includes interactions between infant mortality and indicators for whether your father worked in a lower (unskilled, partly-skilled, or skilled manual/non-manual) or higher (managerial/technical or professional) social class occupation when the child was 14 . In the regression, we include interactions between mortality and both SES categories and exclude the main infant mortality effect. Estimates in Table 4 indicate that for most outcomes the effect of the infant mortality shock on adult outcomes is statistically the same for those from lower and higher SES families.

\footnotetext{
${ }^{18}$ If we apply the Holm-Bonferroni correction for multiple hypothesis testing, the estimates associated with having a job and disability remain significant. Note, however, that the Holm-Bonferroni correction is overly conservative because it assumes that estimates are independent, which is not the case.
} 
However, the estimates for whether a person reports very good/excellent health, has a job, reports no income, and owns a home do statistically differ. For these outcomes, the estimate for the high socioeconomic group is statistically smaller than the estimate for the low socioeconomic group as indicated by the P-values reported in column (3) that test the equality of the estimates for the low and high SES groups. However, note that for two of these outcomes, very good/excellent health and owns home, neither of the infant mortality-by-SES interactions from columns (1) and (2) are statistically different from zero. These results suggest that, in general, either exposure to the shock was no worse for those in lower and higher SES households or that family SES did little to moderate the relationship, with the exception related to whether a person works and has income.

In Table 5, we explore whether the infant mortality effects differ by age. To do so, we estimate equation (3), allowing the effect of infant mortality to differ by age, which is measured as indicators denoting age groups. 40 to 53; 54 to 59; and 60 to 73 . In the regression, we include all interactions and exclude the main infant mortality effect. ${ }^{19}$ The results from Table 5 are consistent with those in Table 3, but show that the adverse effects of mortality are concentrated later in life. For instance, the effect of infant mortality on the probability of reporting a disability grow monotonically with terciles of age, with estimates suggesting a standard deviation increase in infant mortality is associated with a roughly $20 \%$ increase in disability relative to the mean for those aged 40 to 53 compared to roughly $45 \%$ for those 60 and over. A similar pattern emerges for self-reported poor or very poor health, the presence of chest/breathing problems, the

\footnotetext{
${ }^{19}$ We also estimated a specification interacting infant mortality and a quadratic in age, and calculated the partial effects of mortality on the outcomes at the midpoints of the age terciles. The partial effects at these ages line up closely with the effects by age terciles (available upon request).
} 
probability of having a job, and real annual labor income, with associations becoming larger at later ages.

\section{Sensitivity Analyses}

In Table 6, we report a variety of sensitivity analyses that address possible concerns related to sample selection and the measurement of infant mortality.

\section{Altering the Birth Cohorts Examined}

As noted earlier, our sample includes individuals born between 1935 and 1950. One potential problem with including cohorts born before 1940 is that there was also an unusually large increase in mortality of children ages 2 to 5 in 1940 and 1941 (see Figure 3). Therefore, children born in these earlier cohorts may have been exposed to a poor health environment, but at later ages. Including cohorts born before the shock may attenuate estimates if older children (e.g. those born in 1935 who would be 6 or 7 in 1940/41) were themselves harmed by the 194041 health environment. We assess this hypothesis by re-estimating the regression model with a sample that excludes these earlier cohorts. We also explore whether our estimates are sensitive to using different ending birth cohorts instead of 1950, specifically, 1945 and 1955. For comparison, column 1 of Table 6 replicates column 3 of Table 3.

In column 2 of Table 6 , we present estimates from a model that includes cohorts born between 1940 and 1950, leaving roughly 26,500 person-by-wave observations. Comparing estimates in columns (1) and (2) indicates that there is little difference, particularly for estimates that were previously statistically significant. The similarity of estimates and lack of attenuation when earlier birth cohorts are included suggests that the effect of health shocks in infancy are more important than health shocks at later childhood ages. This result is consistent with the 
hypothesis that infancy is a critical period for development and that shocks to health during this period have particularly long-lasting effects (Knudson 2004; Heckman et al. 2006; GranthamMcGregor et al. 1997; Grantham-McGregor et al. 2007; Hoddinott and Kinsey 2001; Maccini and Yang 2009; and Maluccio et al. 2008).

Estimates in columns 3 and 4, which alter the ending year of the birth cohorts included, are also consistent with those in Table 3. Estimates using 1935 to 1945 birth cohorts consist of roughly 21,000 person-by-wave observations while those based on 1935 to 1955 birth cohorts consist of roughly 46,500 person-by-wave observations. These estimates show that the adverse effects of infant mortality are not sensitive to the sample period. Overall, changing the beginning or ending period of birth cohorts has relatively little effect on the estimates. ${ }^{20}$

\section{Using Only One Observation per Individual}

As noted earlier, the average individual is observed in approximately 9.5 waves of the survey, with a standard deviation of 6 . To address any concern that estimates and standard errors may be biased by using multiple observations per person, we re-estimate models using a sample consisting of a randomly selected observation for each person. So, the sample for this analysis consists of the roughly 3,200 unique individuals with characteristics that have the same distribution as the full sample. The results from this analysis are presented in column 5 of Table 6.

Qualitatively, estimates in column 5 are similar to other estimates and indicate that infant health shocks are associated with adverse adult health. For example, a one standard deviation increase in infant mortality is associated with approximately a 3.98 percentage point increase in disability, nearly identical to the original estimate. We note that standard errors using the

\footnotetext{
${ }^{20}$ The one exception to this conclusion may be estimates for whether a person has a chest/breathing problem.
} 
randomly selected sample are similar, though somewhat larger, compared to estimates using all person-year observations.

\section{Using Only the 1940 and 1941 Variation in Infant Mortality}

The inclusion of district and birth year fixed effects controls for much of the variation in infant mortality over the sample period unrelated to the shock in 1940 and 1941. For example, a regression of infant mortality on region fixed effects and birth year fixed effects has an R-square of approximately 0.87 -implying that $87 \%$ of the variation in infant mortality is explained by these fixed effects alone. After including region-specific linear time trends, the share of explained variation rises to $91 \%$. This is consistent with the evidence in Figures 1-4, which shows that other than 1940 and 1941, infant mortality follows a very predicable trend during the period. Thus, the only meaningful variation in infant mortality that remains is arguably driven by deviations from trend in 1940 and 1941.

Nevertheless, one may argue that the use of all the variation in infant mortality may induce bias from endogenous changes in infant mortality unrelated to the wartime conditions that we have argued are largely exogenous. To assess this possibility, we use an alternative measure of treatment. Specifically, we set infant mortality to the UK linear trend in all years except 1940 and 1941, and use this measure of treatment in the regression. Effectively, this approach mechanically removes all variation in years away from the years of the shock to infant mortality, given the birth year fixed effects. If the estimates remain similar, this suggests that variation away from the shock does not drive our findings.

In column 6 of Table 6 , we report estimates obtained using this alternative measure of treatment. The estimates from this approach are consistent with those in column 1 and similar in 
sign, magnitude and statistical significance, which suggests that variation away from the shock period in 1940 and 1941 does not drive our findings.

\section{Omitting London}

Finally, because residents of London experienced the greatest amount of relocation during the war, there is a concern about potential measurement error in infant mortality. To address this, we re-estimating our primary specification omitting people who reported being born in London, which drops roughly 3,230 person-by-wave observations (Column 7 of Table 6). A comparison between estimates in Column 7 and Column 1 (original estimates) indicates that they are very similar suggesting that any measurement error introduced by dislocation does not affect estimates.

\section{Conclusion}

The marked increase in infant mortality in England and Wales during WWII represents a severe infant health shock. As other research has suggested, such adverse health shocks early in life may have long lasting effects. In this paper, we add to that literature by examining how the spike in infant mortality in Great Britain at the start of WWII affected adult outcomes. Historical evidence suggests that the sharp rise in infant mortality in England in 1940 and 1941 was largely driven by a combination of a wartime food rationing program, unusually harsh winters, and overcrowded day nurseries. Moreover, the extent of the adverse health shocks varied considerably across regions within England. It is this plausibly exogenous variation in infant health, arising largely due to greater rates of infectious disease, which we exploit to obtain estimates of the effect of early life health on adult outcomes. 
We find that the wartime spike in infant mortality had a negative effect on later-life outcomes. The results are consequential in magnitude. We find that a one standard deviation increase in the district infant mortality rate (roughly the size of the increase between 1939 and 1941) was associated with a $24 \%$ increase in reporting poor/very poor health; a $35 \%$ increase in reporting a disability; a $10 \%$ decrease in the probability of having a job at the time of interview; a $17 \%$ increase in reporting no annual real earned income; and a roughly $9 \%$ decrease in reporting top-tercile (>12954 pounds) annual real earned income.

One contribution of our study was focusing on recent birth cohorts, as relatively few studies have done so. Bozzoli et al. (2009) reported that, for birth cohorts from a comparable period as those in our sample, higher rates of post-neonatal mortality from pneumonia, which is similar to our context, was the most consistent predictor of lower adult height in the US and European countries. The effect size for the US implied by these estimates is small—-the change in post-neonatal mortality rate in the US from 1950 to 1980 is predicted to have increased adult height by 0.2 centimeters. Case and Paxson (2009), reported that higher rates of infant mortality among US cohorts born between 1910 and 1950 were associated with reduced cognitive function. Here too, the effect size was quite small; a 50\% increase in infant mortality rates were associated with one-tenth of a standard deviation decrease in cognitive test (word recall) score. Our estimates also show scarring effects of infant health shocks like these studies, but our effect sizes are larger.

Several other findings merit note. First, we found that the health environment during infancy was particularly important, and that there was no evidence that a poor health environment at later ages (2 to 5 ) had any meaningful effect on adult wellbeing. This evidence suggests that the first year of life may be a critical period influencing adult outcomes (Heckman 
2007). Second, while descriptive evidence suggested that there was a fertility response to WWII and that average family size differed by birth cohort, this variation in fertility was not a confounding factor of the effect of infant mortality. Third, we found little evidence that higher socioeconomic status moderated the effect of the infant health shock. Finally, the evidence was clear that the association between the early life health shock and adult outcomes grew with age and were more present after age 55 .

In summary, the findings of our study add to the literature documenting the adverse effects on adult health and socioeconomic status of early life health shocks. Our study examined the effects of a specific health shock during a narrowly defined age (post-neonatal) on adult outcomes for a contemporary population of adults in a developed country setting-England and Wales. Whether these findings are relevant to today is unknown, but poor infant health remains a problem among disadvantaged populations in developed countries. It is possible that the effects of such poor health on future adult outcomes may be diminished by current medical technology, and social and economic institutions, but if so, then this beneficial effect underscores the importance of these mediating forces. If not, then our results highlight the potential for significant benefits from interventions targeted at improving infant health. 


\section{Bibliography}

Akbulut-Yuksel, Mevlude. 2014. "Children of War: The Long-Run Effects of Large-Scale Physical Destruction and Warfare on Children." Journal of Human Resources 49 (3):634-62.

Akresh, Richard, Sonia Bhalotra, Marinella Leone, and Una Okonkwo Osili. 2012. "War and Stature: Growing Up during the Nigerian Civil War." American Economic Review 102 (3):273-77. https://doi.org/10.1257/aer.102.3.273.

Almond, Douglas. 2006. "Is the 1918 Influenza Pandemic Over? Long-Term Effects of In Utero Influenza Exposure in the Post-1940 U.S. Population." Journal of Political Economy 114 (4):672-712. https://doi.org/10.1086/507154.

Almond, Douglas, and Janet Currie. 2011. "Killing Me Softly: The Fetal Origins Hypothesis." Journal of Economic Perspectives 25 (3):153-72. https://doi.org/10.1257/jep.25.3.153.

Almond, Douglas, Janet Currie, and Mariesa Herrmann. 2012. "From Infant to Mother: Early Disease Environment and Future Maternal Health.” Labour Economics 19 (4):475-83. https://doi.org/10.1016/j.labeco.2012.05.015.

Almond, Douglas, Lena Edlund, and Mårten Palme. 2007. "Chernobyl’s Subclinical Legacy: Prenatal Exposure to Radioactive Fallout and School Outcomes in Sweden.” Working Paper 13347. National Bureau of Economic Research. http://www.nber.org/papers/w13347.

Almond, Douglas, and Bhashkar Mazumder. 2005. "The 1918 Influenza Pandemic and Subsequent Health Outcomes: An Analysis of SIPP Data." American Economic Review 95 (2):258-62.

Banerjee, Abhijit, Esther Duflo, Gilles Postel-Vinay, and Tim Watts. 2010. "Long-Run Health Impacts of Income Shocks: Wine and Phylloxera in Nineteenth-Century France." The Review of Economics and Statistics 92 (4):714-28. https://doi.org/10.1162/REST_a_00024.

Barker, D. J., and C. Osmond. 1986. "Infant Mortality, Childhood Nutrition, and Ischaemic Heart Disease in England and Wales." Lancet (London, England) 1 (8489):1077-81.

Bengtsson, Tommy, and Göran Broström. 2009. "Do Conditions in Early Life Affect Old-Age Mortality Directly and Indirectly? Evidence from 19th-Century Rural Sweden." Social Science \& Medicine (1982) 68 (9):1583-90. https://doi.org/10.1016/j.socscimed.2009.02.020.

Bengtsson, Tommy, and Martin Lindstrom. 2000. "Childhood Misery and Disease in Later Life: The Effects on Mortality in Old Age of Hazards Experienced in Early Life, Southern Sweden, 1760-1894." Population Studies 54 (3):263-77.

Ben-Porath, Yoram. 1976. "Fertility Response to Child Mortality: Micro Data from Israel." Journal of Political Economy 84 (4):S163-78.

Ben-Shlomo, Y., and G. D. Smith. 1991. "Deprivation in Infancy or in Adult Life: Which Is More Important for Mortality Risk?” Lancet (London, England) 337 (8740):530-34.

Berg, Gerard J. van den, Maarten Lindeboom, and France Portrait. 2006. "Economic Conditions Early in Life and Individual Mortality." American Economic Review 96 (1):290-302. https://doi.org/10.1257/000282806776157740.

Bharadwaj, Prashant, Katrine Vellesen L?ken, and Christopher Neilson. 2013. "Early Life Health Interventions and Academic Achievement." American Economic Review 103 (5):186291. 
Bleakley, Hoyt. 2007. "Disease and Development: Evidence from Hookworm Eradication in the American South." The Quarterly Journal of Economics 122 (1):73-117. https://doi.org/10.1162/qjec.121.1.73.

- 2010. "Malaria Eradication in the Americas: A Retrospective Analysis of Childhood Exposure." American Economic Journal: Applied Economics 2 (2):1-45. https://doi.org/10.1257/app.2.2.1.

Bozzoli, Carlos, Angus Deaton, and Climent Quintana-Domeque. 2009. "Adult Height and Childhood Disease." Demography 46 (4):647-69.

Brown, Ryan, and Duncan Thomas. 2013. "On the Long Term Effects of the 1918 U.S. Influenza Pandemic." http://sites.duke.edu/ryanbrown/files/2013/09/1918Flu_Brown_Thomas_20131.pdf.

Case, Anne, and Christina Paxson. 2009. "Early Life Health and Cognitive Function in Old Age." The American Economic Review 99 (2):104-9. https://doi.org/10.1257/aer.99.2.104.

Catalano, Ralph, and Tim Bruckner. 2006. "Secondary Sex Ratios and Male Lifespan: Damaged or Culled Cohorts." Proceedings of the National Academy of Sciences 103 (5):1639-43. https://doi.org/10.1073/pnas.0510567103.

Chen, Yuyu, and Li-An Zhou. 2007. "The Long-Term Health and Economic Consequences of the 1959-1961 Famine in China." Journal of Health Economics 26 (4):659-81. https://doi.org/10.1016/j.jhealeco.2006.12.006.

Crimmins, Eileen M., and Caleb E. Finch. 2006. "Infection, Inflammation, Height, and Longevity." Proceedings of the National Academy of Sciences of the United States of America 103 (2):498-503. https://doi.org/10.1073/pnas.0501470103.

Cutler, David M., Grant Miller, and Douglas M. Norton. 2007. "Evidence on Early-Life Income and Late-Life Health from America's Dust Bowl Era." Proceedings of the National Academy of Sciences 104 (33):13244-49. https://doi.org/10.1073/pnas.0700035104.

Dinkelman, Taryn. 2017. "Long-Run Health Repercussions of Drought Shocks: Evidence from South African Homelands." The Economic Journal, February, n/a-n/a. https://doi.org/10.1111/ecoj.12361.

Elo, Irma T., and Samuel H. Preston. 1992. "Effects of Early-Life Conditions on Adult Mortality: A Review.” Population Index 58 (2):186-212. https://doi.org/10.2307/3644718.

Franks, P., M.R. Gold, and K. Fiscella. 2003. "Sociodemographics, self-rated health, and mortality in the US." Social Science and Medicine, Jun;56(12), 2505-14

Grantham-McGregor, Sally M., Susan P. Walker, Susan M. Chang, and Christine A. Powell, "Effects of early childhood supplementation with and without stimulation on later development in stunted Jamaican children.," The American Journal of Clinical Nutrition, 1997, 66 (2), 247- 253.

Grantham-McGregor, Sally, Yin Bun Cheung, Santiago Cueto, Paul Glewwe, Linda Richter, Barbara Strupp, and the International Child Development Steering Group, "Child development in developing countries 1: Developmental potential in the first 5 years for children in developing countries," Lancet, January 6 2007, 369, 60-70

Great Britain Ministry of Health. 1946. On the State of the Public Health during Six Years of War Report of the Chief Medical Officer of the Ministry of Health. London: Her Majesty's Stationary Office. 
Griffiths, C, and A Brock. 2003. "Twentieth Century Mortality Trends in England and Wales." Health Statistics Quarterly 18:5-18.

Havari, Enkelejda, and Franco Peracchi. 2017. "Growing up in Wartime: Evidence from the Era of Two World Wars." Economics \& Human Biology, In Honor of Nobel Laureate Angus Deaton: Health Economics in Developed and Developing Countries, 25 (May):9-32. https://doi.org/10.1016/j.ehb.2016.09.002.

Heckman, James J., Judy L. Cameron, and Jack P. Shonkoff, "Economic, neurobiological, and behavioral perspectives on building America's future workforce," Proceedings of the National Academy of Sciences, July 5 2006, 103 (27), 10155-10162.

Heckman, James J., "The economics, technology, and neuroscience of human capability formation." PNAS August 14, 2007104 (33) 13250-13255

Hoddinott, John and Bill Kinsey, "Child growth in the time of drought," Oxford Bulletin of Economics and Statistics, 2001, 63 (4), 409-436.

Idler, E.L. and Y. Benyamini. 1997. "Self-rated health and mortality: a review of twenty-seven community studies." Journal of Health and Social Behavior, March,38(1): 21-37.

Imbens, Guido W., and Donald B. Rubin. 2015. Causal Inference for Statistics, Social, and Biomedical Sciences: An Introduction. New York, NY, USA: Cambridge University Press.

Johnson, Derek E. 1985. Exodus of Children: Story of the Evacuation, 1939-45. Clacton-on-Sea: Pennyfarthing Publications.

Jonas Hjort, Mikkel Sølvsten, and Miriam Wüst. Forthcoming. "Universal Investment in Infants and Long-Run Health: Evidence from Denmark's 1937 Home Visiting Program." American Economic Journal: Applied Economics.

Kannisto, V, K Christensen, and J W Vaupel. 1997. "No Increased Mortality in Later Life for Cohorts Born during Famine." American Journal of Epidemiology 145 (11):987-94.

Kelly, Elaine. 2011. "The Scourge of Asian Flu: In Utero Exposure to Pandemic Influenza and the Development of a Cohort of British Children." Journal of Human Resources 46 (4):669-94.

Kesternich, Iris, Bettina Siflinger, James P. Smith, and Joachim K. Winter. 2014. "The Effects of World War II on Economic and Health Outcomes across Europe." The Review of Economics and Statistics 96 (1):103-18. https://doi.org/10.1162/REST_a_00353.

Knudsen, Eric I., "Sensitive Periods in the Development of the Brain and Behavior," Journal of Cognitive Neuroscience, 2004, 16 (8), 1412-1425. ,

Lee, Chulhee. 2014. "In Utero Exposure to the Korean War and Its Long-Term Effects on Socioeconomic and Health Outcomes." Journal of Health Economics 33 (January):7693. https://doi.org/10.1016/j.jhealeco.2013.11.002.

Lindeboom, Maarten, France Portrait, and Gerard J. van den Berg. 2010. "Long-Run Effects on Longevity of a Nutritional Shock Early in Life: The Dutch Potato Famine of 1846-1847." Journal of Health Economics 29 (5):617-29. https://doi.org/10.1016/j.jhealeco.2010.06.001.

Lucas, Adrienne M. 2010. "Malaria Eradication and Educational Attainment: Evidence from Paraguay and Sri Lanka." American Economic Journal: Applied Economics 2 (2):46-71. https://doi.org/10.1257/app.2.2.46.

Lumey, L. H., Aryeh D. Stein, and Ezra Susser. 2011. "Prenatal Famine and Adult Health." Annual Review of Public Health 32:237-62. https://doi.org/10.1146/annurev-publhealth031210-101230. 
Maccini, Sharon and Dean Yang, "Under the Weather: Health, Schooling, and Economic Consequences of Early-Life Rainfall,” American Economic Review, 2009, 99 (3), 10061026.

John A Maluccio, Jere R Behrman, Rafael Flores, and Reynaldo Martorell, "Effect of a nutrition intervention during early childhood on economic productivity in Guatemalan adults," The Lancet, 2008, 371, 411-416.

McNally, J. Dayre, Karen Leis, Loren A. Matheson, Chandima Karuananyake, Koravangattu Sankaran, and Alan M. Rosenberg. 2009. "Vitamin D Deficiency in Young Children with Severe Acute Lower Respiratory Infection.” Pediatric Pulmonology 44 (10):981-88. https://doi.org/10.1002/ppul.21089.

"Monthly Weather Reports 1940s." n.d. Met Office. Accessed March 2, 2016. http://www.metoffice.gov.uk/learning/library/archive-hidden-treasures/monthly-weatherreport-1940s.

Muhe, L., S. Lulseged, K. E. Mason, and E. A. Simoes. 1997. "Case-Control Study of the Role of Nutritional Rickets in the Risk of Developing Pneumonia in Ethiopian Children." Lancet (London, England) 349 (9068):1801-4. https://doi.org/10.1016/S01406736(96)12098-5.

Myrskylä, Mikko. 2010. "The Relative Effects of Shocks in Early- and Later-Life Conditions on Mortality." Population and Development Review 36 (4):803-29. https://doi.org/10.1111/j.1728-4457.2010.00358.x.

Neelsen, Sven, and Thomas Stratmann. 2011. "Effects of Prenatal and Early Life Malnutrition: Evidence from the Greek Famine." Journal of Health Economics 30 (3):479-88. https://doi.org/10.1016/j.jhealeco.2011.03.001.

Orr, J.B. (1937). Food health and income (2 $2^{\text {nd }}$ edition). London: Macmillan.

Quaranta, Luciana. 2014. "Early life effects across the life course: The impact of individually defined exogenous measures of exposure on mortality by sex in 19th and 20th century Southern Sweden." Social Science and Medicine 119: 266-273

Roseboom, T J, J H van der Meulen, A C Ravelli, C Osmond, D J Barker, and O P Bleker. 2001. "Effects of Prenatal Exposure to the Dutch Famine on Adult Disease in Later Life: An Overview." Molecular and Cellular Endocrinology 185 (1-2):93-98.

Schellekens, Jona, and Frans van Poppel. 2016. "Early-Life Conditions and Adult Mortality Decline in Dutch Cohorts Born 1812-1921." Population Studies 70 (3):327-43. https://doi.org/10.1080/00324728.2016.1223336.

Smallman-Raynor, Matthew, Cathryn Nettleton, and Andrew Cliff. 2003. "Wartime evacuation and the spread of infectious diseases: epidemiological consequences of the dispersal of children from London during World War II." Journal of Historical Geography 29(3): 396421.

Stanner, S. A., K. Bulmer, C. Andres, O. E. Lantseva, V. Borodina, V. V. Poteen, and J. S. Yudkin. 1997. "Does Malnutrition in Utero Determine Diabetes and Coronary Heart Disease in Adulthood? Results from the Leningrad Siege Study, a Cross Sectional Study." BMJ : British Medical Journal 315 (7119):1342-48.

University of Essex. Institute for Social and Economic Research. 2010. "British Household Panel Survey: Waves 1-18, 1991-2009 [Data Collection]." 7th Edition. UK Data Service. SN: 5151. https://doi.org/http://doi.org/10.5255/UKDA-SN-5151-1.

Van Ewijk R, Lindeboom M (2017), Why People Born During World War II are Healthier, GSME Discussion Paper No. 1619, Mainz, Germany. 
Wayse, V., A. Yousafzai, K. Mogale, and S. Filteau. 2004. "Association of Subclinical Vitamin D Deficiency with Severe Acute Lower Respiratory Infection in Indian Children under 5 Y." European Journal of Clinical Nutrition 58 (4):563-67. https://doi.org/10.1038/sj.ejcn.1601845.

Wonodi, Chizoba B., Maria Deloria-Knoll, Daniel R. Feikin, Andrea N. DeLuca, Amanda J. Driscoll, Jennifer C. Moïsi, Hope L. Johnson, et al. 2012. "Evaluation of Risk Factors for Severe Pneumonia in Children: The Pneumonia Etiology Research for Child Health Study." Clinical Infectious Diseases: An Official Publication of the Infectious Diseases Society of America 54 (Suppl 2):S124-31. https://doi.org/10.1093/cid/cir1067. 


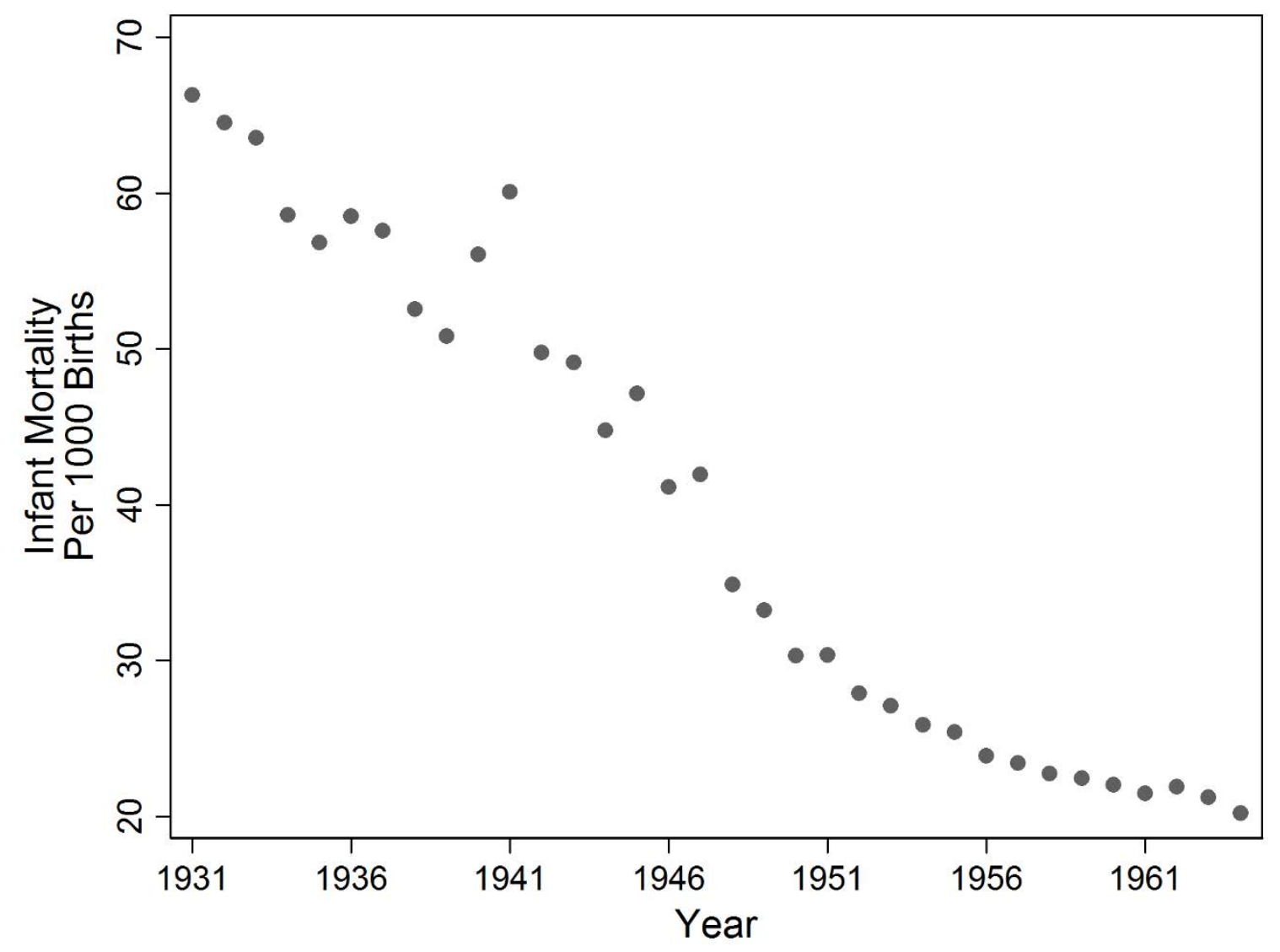

Fig. 1. Infant Mortality (Per 1,000 Births) in England - 1931 to 1964

Source: Authors calculations from table "mort_lgd" in the database of "Birth \& Death Statistics for local

Government Districts from 1921-1974."

Notes: In the figure we plot aggregate infant mortality by year for those born in England between 1931 to 1964. 


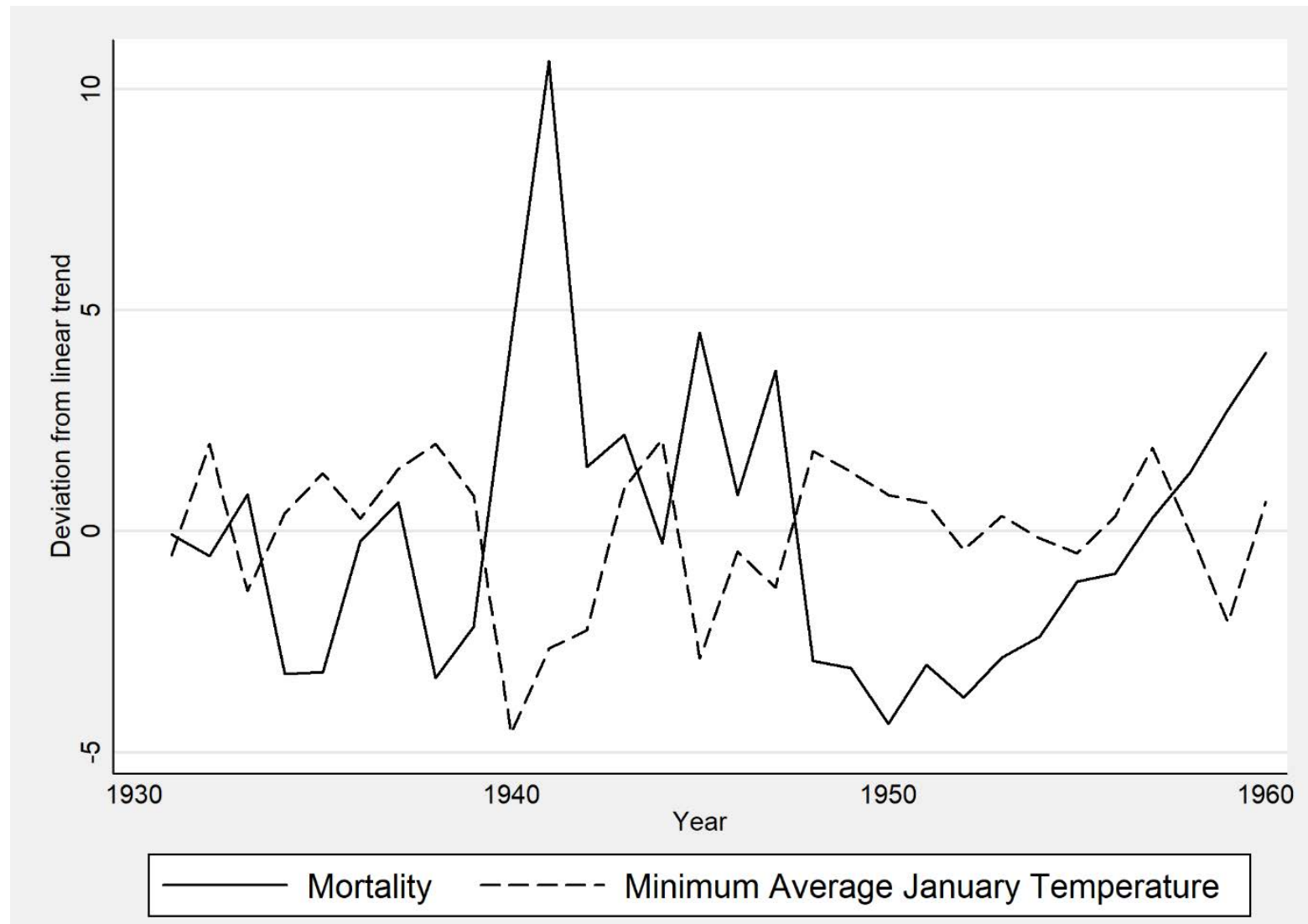

Fig. 2 Deviations in Infant Mortality (Per 1,000 Births) and Minimum January Temperatures in England - 1931 to 1960

Source: Authors calculations from table "mort lgd" in the database of "Birth \& Death Statistics for Local Government Districts from 1921-1974" and data from the MET office on average minimum temperatures available at http://www.metoffice.gov.uk/public/weather/climate-historic/\#?tab=climateHistoric (last accessed 7 August 2017). Notes: This figure plots deviations from a county linear trend in infant mortality and temperature from 1931 to 1960. 


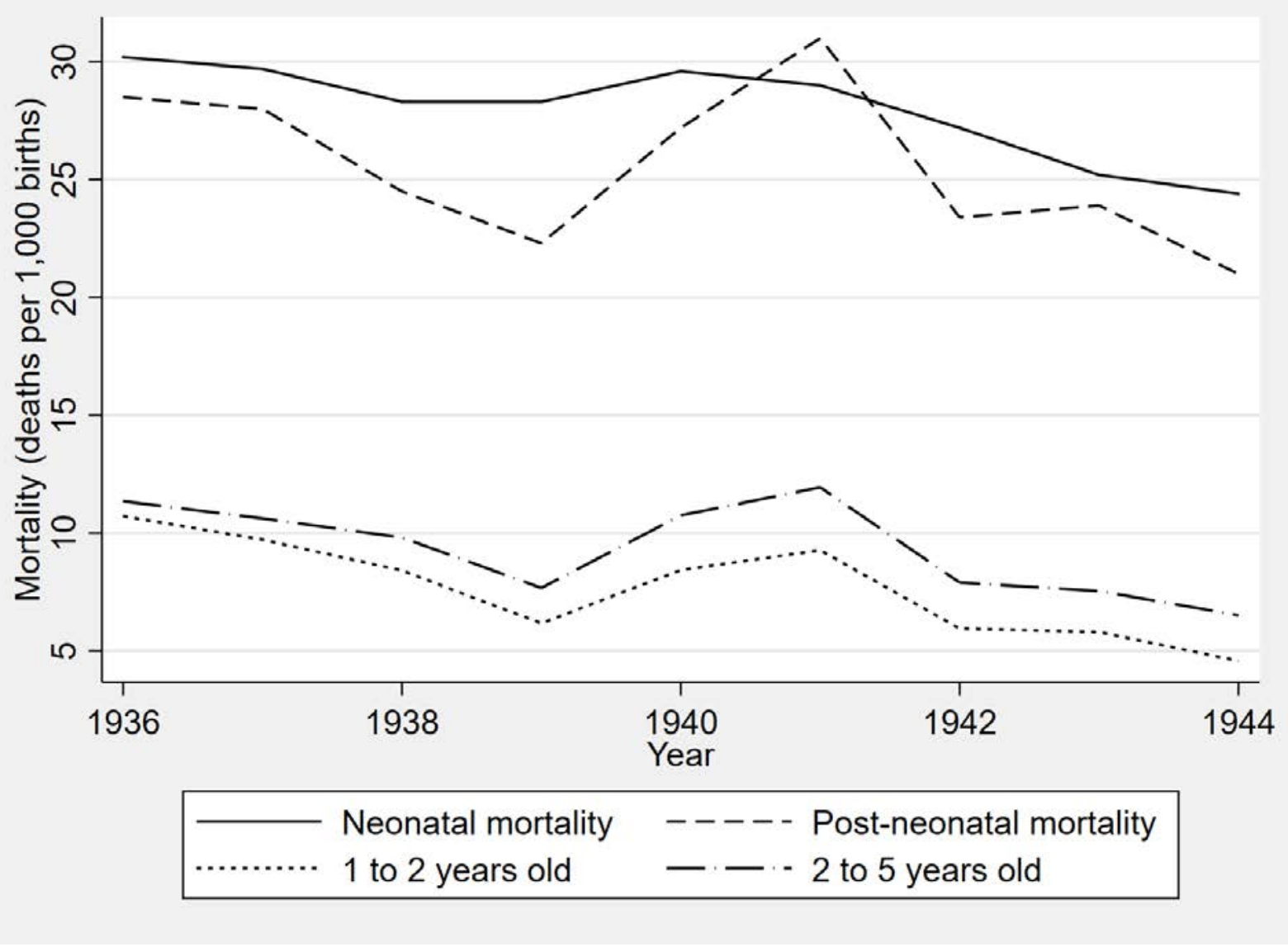

Year

Fig. 3 Mortality by Age, Deaths per 1,000 live births, England and Wales

Source: Authors calculations based on data from On the State of the Public Health During the Six Years of War (1946)

Notes: This figure plots neonatal (0 to 1 month) and post-neonatal mortality ( 1 to 12 months), and childhood mortality (aged 1 to 2 years and 2 to 5 years) in England and Wales. The figure illustrates that the aggregate spike observed in Figure 1 was driven largely by an increase in post-neonatal mortality. 


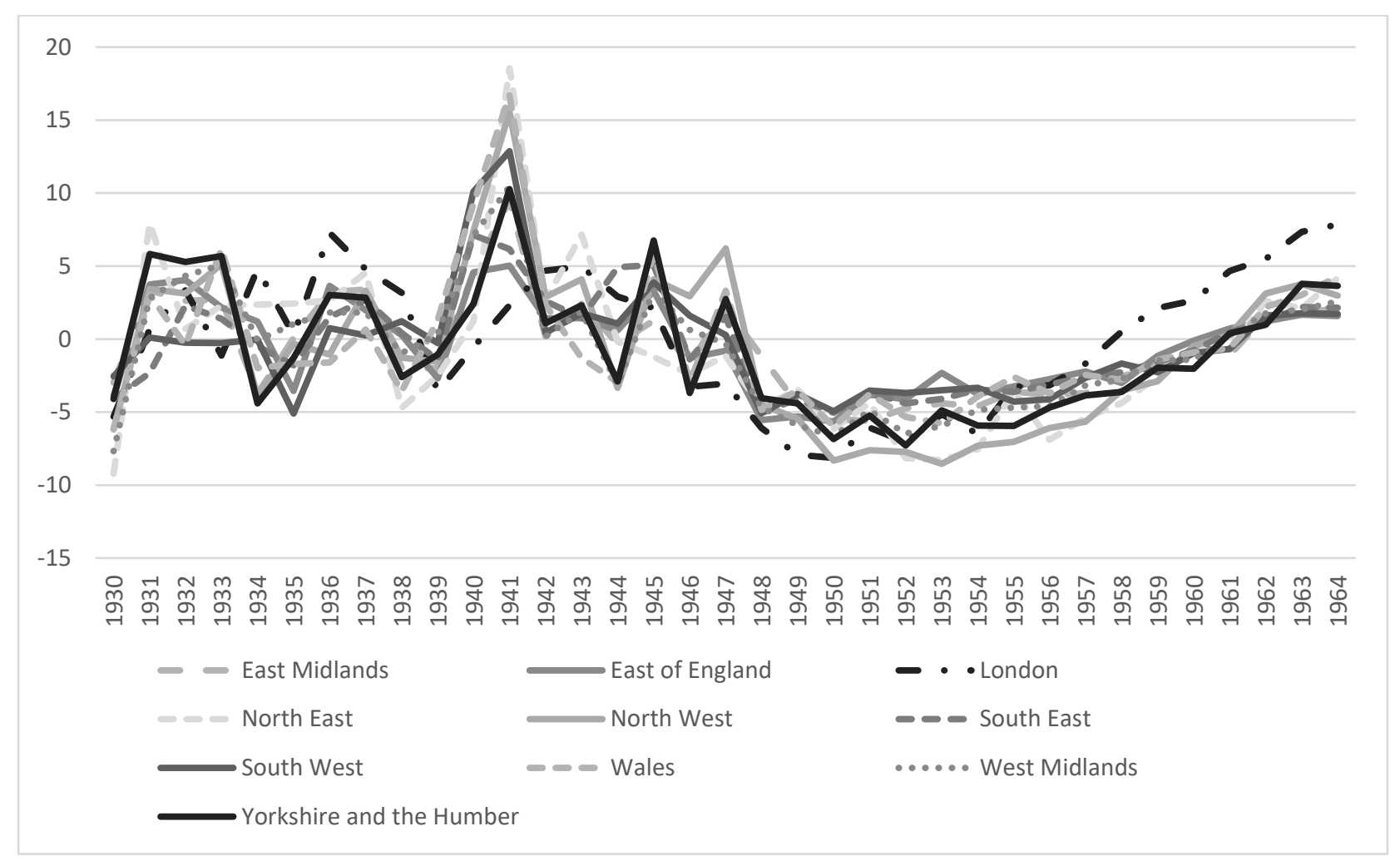

Fig. 4 Deviations in Infant Mortality (Per 1,000 Births) from within-Region Trend - 1930 to 1964

Source: Authors calculations from table "mort lgd" in the database of "Birth \& Death Statistics for Local Government Districts from 1921-1974."

Notes: This figure plots deviations from a region-specific linear trend in infant mortality from 1930 to 1964 . It illustrates that there is substantial variation within the country in the extent to which infant mortality increased. 
Table 1

Causes of infant mortality by year

\begin{tabular}{|c|c|c|c|c|c|c|c|c|c|c|c|}
\hline & \multicolumn{11}{|c|}{ Infant mortality by cause of death (measured as infant deaths per 1,000 live births) } \\
\hline & 1939 & 1940 & $\begin{array}{c}\text { Change } \\
1940-1939\end{array}$ & $\begin{array}{c}\text { Share of } \\
\text { Total } \\
\text { Change } \\
\text { 1940-1939 }\end{array}$ & 1940 & 1941 & $\begin{array}{c}\text { Change } \\
1941-1940\end{array}$ & $\begin{array}{c}\text { Share of Total } \\
\text { Change } 1941- \\
1940\end{array}$ & 1942 & $\begin{array}{c}\text { Change } \\
1942-1941\end{array}$ & $\begin{array}{c}\text { Share of Total } \\
\text { Change 1942- } \\
1941\end{array}$ \\
\hline $\begin{array}{l}\text { Bronchitis and } \\
\text { pneumonia }\end{array}$ & 8.9 & 12.7 & 3.8 & 60.8 & 12.7 & 13.7 & 1.0 & 31.4 & 9.2 & -4.5 & 47.6 \\
\hline Whooping Cough & 1.1 & 0.6 & -0.5 & -7.9 & 0.6 & 2.1 & 1.5 & 46.6 & 0.8 & -1.3 & 13.7 \\
\hline Measles & 0.1 & 0.4 & 0.3 & 4.8 & 0.4 & 0.6 & 0.2 & 6.1 & 0.2 & -0.4 & 4.2 \\
\hline Tuberculosis diseases & 0.5 & 0.6 & 0.1 & 1.6 & 0.6 & 0.7 & 0.1 & 3.1 & 0.5 & -0.2 & 2.1 \\
\hline Convulsions & 1.2 & 1.2 & 0.0 & 0.0 & 1.2 & 1.3 & 0.1 & 3.0 & 1.0 & -0.3 & 3.1 \\
\hline Enteritis and diarrhea & 4.3 & 4.4 & 0.1 & 1.4 & 4.4 & 4.8 & 0.4 & 12.2 & 5.2 & 0.4 & 4.0 \\
\hline $\begin{array}{l}\text { Congenital } \\
\text { malformations }\end{array}$ & 6.1 & 6.6 & 0.5 & 7.7 & 6.6 & 6.6 & 0.0 & 0.0 & 6.5 & -0.1 & 1.4 \\
\hline Premature birth & 14.9 & 14.5 & -0.4 & -7.1 & 14.5 & 14.7 & 0.2 & 8.9 & 13.7 & -1.0 & 10.8 \\
\hline Injury at birth & 2.7 & 2.7 & 0.0 & 0.0 & 2.7 & 2.6 & -0.1 & -3.3 & 2.6 & 0.0 & 0.0 \\
\hline Asphyxia, atelectasis & 2.1 & 2.3 & 0.2 & 3.3 & 2.3 & 2.2 & -0.1 & -2.8 & 2.0 & -0.2 & 2.1 \\
\hline Congenital debility & 1.7 & 2.1 & 0.4 & 6.5 & 2.1 & 2.1 & 0.0 & 0.0 & 1.6 & -0.5 & 5.3 \\
\hline Hemolytic disease & 0.5 & 0.5 & 0.0 & 0.0 & 0.5 & 0.5 & 0.0 & 0.0 & 0.6 & 0.1 & 1.0 \\
\hline Other causes & 6.5 & 8.3 & 1.8 & 28.9 & 8.3 & 8.2 & -0.1 & -5.1 & 6.8 & -1.4 & 14.5 \\
\hline Total & 50.6 & 56.9 & 6.3 & 100 & 56.9 & 60.1 & 3.2 & 100 & 50.6 & -9.5 & 100 \\
\hline
\end{tabular}

Source. Based on statistics from Table IV on page 262 of On the State of the Public Health during Six Years of War Report of the Chief Medical Officer of the Ministry of Health (1946).

Notes. We present cause-specific infant mortality by year. For instance, in 1939 bronchitis and pneumonia deaths were the cause of 8.9 infant deaths per every 1,000 live births. Between 1939 and 1940, bronchitis and pneumonia deaths rose to 12.7 infant deaths per every 1,000 live births, a change of 3.8. Between 1939 and 1940, the total change in infant deaths per live births was 6.3. As a share of the total change, the rise in bronchitis and pneumonia deaths explain 60.8 percent. 
Table 2

Descriptive Statistics

\begin{tabular}{lccc}
\hline & Mean & Std. Dev. & $\mathrm{N}$ \\
\cline { 2 - 4 } Infant Mortality per 1,000 Live Births & 45.57 & 13.45 & 34684 \\
Birth Rate per 1,000 total population & 17.44 & 2.82 & 34684 \\
Good or Excellent Self-Reported Health & 0.68 & 0.47 & 34275 \\
Poor or Very Poor Health & 0.12 & 0.32 & 34275 \\
Has Recent Inpatient Visits & 0.09 & 0.29 & 34321 \\
Has Reported Health Problems & 0.69 & 0.46 & 34197 \\
Has Arm/Leg/Hand Problem & 0.38 & 0.49 & 34197 \\
Has Chest/Breathing Problem & 0.13 & 0.34 & 34197 \\
Has Heart/BP Problem & 0.23 & 0.42 & 34197 \\
Disabled & 0.10 & 0.30 & 34268 \\
Has a Job at time of survey & 0.56 & 0.50 & 34321 \\
Has No Reported Annual Income & 0.37 & 0.48 & 33359 \\
Annual Real Income $\geq 1$ and $\leq 12954$ & 0.30 & 0.46 & 33359 \\
Annual Real Income $>$ 12954 & 0.33 & 0.47 & 33359 \\
Annual Real Income (pounds) & 10642.73 & 15206.74 & 33671 \\
Owns Home & 0.83 & 0.38 & 33799 \\
Primary Education Only (ISCED =1) & 0.367 & 0.482 & 3206 \\
Female & 0.54 & 0.50 & 34684 \\
Age & 55.99 & 6.78 & 34684 \\
Birth Year & 1943.4 & 4.45 & 34684 \\
Birth Month & 6.52 & 3.42 & 34684 \\
\hline
\end{tabular}

Notes. We present average sample characteristics for our sample analysis sample. Because our sample contains individuals aged 40 to 73 and education is unlikely to change much at these ages, the sample size for the outcome "college or higher" is based on a random observation from each person in the sample leaving 3206 observations. 
Table 3

Relationship between Infant Mortality Measured at the District-Cohort Level and Adult Health and Socioeconomic Status

\begin{tabular}{|c|c|c|c|c|}
\hline & $(1)$ & $(2)$ & (3) & $(4)$ \\
\hline $\begin{array}{l}\text { Very Good/Excellent Health } \\
\quad(\text { mean }=0.68)\end{array}$ & $\begin{array}{l}-0.0195 \\
(0.0177)\end{array}$ & $\begin{array}{l}-0.0190 \\
(0.0174)\end{array}$ & $\begin{array}{l}-0.0190 \\
(0.0174)\end{array}$ & $\begin{array}{l}-0.0201 \\
(0.0205)\end{array}$ \\
\hline $\begin{array}{l}\text { Poor/Very Poor Health } \\
\quad(\text { mean }=0.12)\end{array}$ & $\begin{array}{l}0.0294 * * \\
(0.0132)\end{array}$ & $\begin{array}{l}0.0290 * * \\
(0.0131)\end{array}$ & $\begin{array}{l}0.0290 * * \\
(0.0131)\end{array}$ & $\begin{array}{l}0.0310^{*} \\
(0.0158)\end{array}$ \\
\hline $\begin{array}{l}\text { Has Recent IP Visits } \\
\quad(\text { mean }=0.09)\end{array}$ & $\begin{array}{c}0.0057 \\
(0.0062)\end{array}$ & $\begin{array}{c}0.0058 \\
(0.0062)\end{array}$ & $\begin{array}{c}0.0057 \\
(0.0063)\end{array}$ & $\begin{array}{c}0.0087 \\
(0.0072)\end{array}$ \\
\hline $\begin{array}{l}\text { Has Reported Health Problems } \\
\quad(\text { mean }=0.69)\end{array}$ & $\begin{array}{c}0.0152 \\
(0.0184)\end{array}$ & $\begin{array}{c}0.0145 \\
(0.0178)\end{array}$ & $\begin{array}{c}0.0145 \\
(0.0178)\end{array}$ & $\begin{array}{c}0.0184 \\
(0.0202)\end{array}$ \\
\hline $\begin{array}{l}\text { Has Arm } / \mathrm{Leg} / \text { Hand Problem } \\
\quad(\text { mean }=0.38)\end{array}$ & $\begin{array}{c}0.0246 \\
(0.0197)\end{array}$ & $\begin{array}{c}0.0231 \\
(0.0189)\end{array}$ & $\begin{array}{c}0.0232 \\
(0.0189)\end{array}$ & $\begin{array}{c}0.0261 \\
(0.0227)\end{array}$ \\
\hline $\begin{array}{l}\text { Has Chest/Breathing Problem } \\
\quad(\text { mean }=0.13)\end{array}$ & $\begin{array}{l}0.0342 * * \\
(0.0154)\end{array}$ & $\begin{array}{l}0.0330^{* *} \\
(0.0154)\end{array}$ & $\begin{array}{l}0.0330^{* *} \\
(0.0154)\end{array}$ & $\begin{array}{l}0.0305^{*} \\
(0.0180)\end{array}$ \\
\hline $\begin{array}{l}\text { Has Heart/BP Problem } \\
\quad(\text { mean }=0.23)\end{array}$ & $\begin{array}{c}0.0015 \\
(0.0153)\end{array}$ & $\begin{array}{l}-0.0014 \\
(0.0153)\end{array}$ & $\begin{array}{l}-0.0016 \\
(0.0153)\end{array}$ & $\begin{array}{l}-0.0006 \\
(0.0196)\end{array}$ \\
\hline $\begin{array}{l}\text { Disabled } \\
\quad(\text { mean }=0.10)\end{array}$ & $\begin{array}{c}0.0363 * * * \\
(0.0110)\end{array}$ & $\begin{array}{c}0.0348^{* * *} \\
(0.0110)\end{array}$ & $\begin{array}{c}0.0348 * * * \\
(0.0110)\end{array}$ & $\begin{array}{c}0.0382 * * * \\
(0.0138)\end{array}$ \\
\hline $\begin{array}{l}\text { Has a Job at time of survey } \\
\quad(\text { mean }=0.56)\end{array}$ & $\begin{array}{c}-0.0558 * * * \\
(0.0172)\end{array}$ & $\begin{array}{c}-0.0574 * * * \\
(0.0163)\end{array}$ & $\begin{array}{c}-0.0574 * * * \\
(0.0163)\end{array}$ & $\begin{array}{c}-0.0471^{* *} \\
(0.0190)\end{array}$ \\
\hline $\begin{array}{l}\text { Primary Education Only }(\text { ISCED }=1) \\
\quad(\text { mean }=0.37)\end{array}$ & $\begin{array}{c}0.0147 \\
(0.0245)\end{array}$ & $\begin{array}{c}0.0214 \\
(0.0242)\end{array}$ & $\begin{array}{c}0.0210 \\
(0.0241)\end{array}$ & $\begin{array}{c}0.0199 \\
(0.0288)\end{array}$ \\
\hline $\begin{array}{l}\text { Has No Reported Annual Income } \\
\quad(\text { mean }=0.37)\end{array}$ & $\begin{array}{c}0.0612 * * * \\
(0.0179)\end{array}$ & $\begin{array}{c}0.0638^{* * *} \\
(0.0171)\end{array}$ & $\begin{array}{c}0.0638^{* * * *} \\
(0.0171)\end{array}$ & $\begin{array}{l}0.0509 * * \\
(0.0198)\end{array}$ \\
\hline $\begin{array}{l}\text { Annual Real Income }>12954 \\
\quad(\text { mean }=0.33)\end{array}$ & $\begin{array}{l}-0.0281 \\
(0.0191)\end{array}$ & $\begin{array}{l}-0.0316^{*} \\
(0.0161)\end{array}$ & $\begin{array}{l}-0.0317^{*} \\
(0.0161)\end{array}$ & $\begin{array}{l}-0.0085 \\
(0.0186)\end{array}$ \\
\hline $\begin{array}{l}\text { Annual Real Income (pounds) } \\
(\text { mean }=10642.73)\end{array}$ & $\begin{array}{l}-830.21 \\
(588.43)\end{array}$ & $\begin{array}{l}-867.27 \\
(530.62)\end{array}$ & $\begin{array}{l}-869.76 \\
(529.55)\end{array}$ & $\begin{array}{l}-116.63 \\
(669.00)\end{array}$ \\
\hline $\begin{array}{l}\text { Owns Home } \\
\qquad(\text { mean }=0.83)\end{array}$ & $\begin{array}{l}-0.0273 \\
(0.0202)\end{array}$ & $\begin{array}{l}-0.0266 \\
(0.0196)\end{array}$ & $\begin{array}{l}-0.0267 \\
(0.0196)\end{array}$ & $\begin{array}{l}-0.0028 \\
(0.0240)\end{array}$ \\
\hline Additional Controls & $\mathrm{N}$ & $\mathrm{Y}$ & Y & $\mathrm{Y}$ \\
\hline Birth Rate & $\mathrm{N}$ & $\mathrm{N}$ & $\mathrm{Y}$ & $\mathrm{Y}$ \\
\hline District-specific linear cohort trends & $\mathrm{N}$ & $\mathrm{N}$ & $\mathrm{N}$ & $\mathrm{Y}$ \\
\hline
\end{tabular}


varies by district and cohort of birth. In column 4, we include district-specific linear cohort trends. Standard errors clustered by district of birth are in parentheses. ${ }^{*} \mathrm{p}<0.10, * * \mathrm{p}<0.05, * * * \mathrm{p}<0.01$ 
Table 4

Relationship between Infant Mortality and Adult Health and Socioeconomic Status By Childhood Socioeconomic Status

(3)

\begin{tabular}{|c|c|c|c|}
\hline & $\begin{array}{c}(1) \\
\text { Low SES }\end{array}$ & $\begin{array}{c}(2) \\
\text { High SES }\end{array}$ & $\begin{array}{c}\text { (3) } \\
\text { P-value for test of } \\
\text { equality }\end{array}$ \\
\hline $\begin{array}{l}\text { Very Good/Excellent Health } \\
\quad(\text { mean }=0.68)\end{array}$ & $\begin{array}{l}-0.0225 \\
(0.0175)\end{array}$ & $\begin{array}{c}0.0042 \\
(0.0221)\end{array}$ & $0.0972 *$ \\
\hline $\begin{array}{l}\text { Poor/Very Poor Health } \\
\quad(\text { mean }=0.12)\end{array}$ & $\begin{array}{c}0.0296 * * \\
(0.0137)\end{array}$ & $\begin{array}{c}0.0236 \\
(0.0144)\end{array}$ & 0.5654 \\
\hline $\begin{array}{l}\text { Has Recent IP Visits } \\
\quad(\text { mean }=0.09)\end{array}$ & $\begin{array}{c}0.0067 \\
(0.0063)\end{array}$ & $\begin{array}{c}0.0042 \\
(0.0085)\end{array}$ & 0.6959 \\
\hline $\begin{array}{l}\text { Has Reported Health Problems } \\
\quad(\text { mean }=0.69)\end{array}$ & $\begin{array}{c}0.0118 \\
(0.0181)\end{array}$ & $\begin{array}{c}0.0282 \\
(0.0250)\end{array}$ & 0.3792 \\
\hline $\begin{array}{l}\text { Has Arm } / \mathrm{Leg} / \text { Hand Problem } \\
\quad(\text { mean }=0.38)\end{array}$ & $\begin{array}{l}0.0229 \\
(0.0193)\end{array}$ & $\begin{array}{c}0.0207 \\
(0.0243)\end{array}$ & 0.9080 \\
\hline $\begin{array}{l}\text { Has Chest/Breathing Problem } \\
\quad(\text { mean }=0.13)\end{array}$ & $\begin{array}{c}0.0332 * * \\
(0.0158)\end{array}$ & $\begin{array}{c}0.0297 \\
(0.0194)\end{array}$ & 0.8209 \\
\hline $\begin{array}{l}\text { Has Heart/BP Problem } \\
\quad(\text { mean }=0.23)\end{array}$ & $\begin{array}{l}-0.0047 \\
(0.0154)\end{array}$ & $\begin{array}{c}0.0153 \\
(0.0248)\end{array}$ & 0.3246 \\
\hline $\begin{array}{l}\text { Disabled } \\
\qquad(\text { mean }=0.10)\end{array}$ & $\begin{array}{l}0.0350 * * * \\
(0.0111)\end{array}$ & $\begin{array}{c}0.0321 * * \\
(0.0138)\end{array}$ & 0.7528 \\
\hline $\begin{array}{l}\text { Has a Job at time of survey } \\
\quad(\text { mean }=0.56)\end{array}$ & $\begin{array}{c}-0.0624 * * * \\
(0.0165)\end{array}$ & $\begin{array}{l}-0.0297 \\
(0.0206)\end{array}$ & $0.0497 * *$ \\
\hline $\begin{array}{l}\text { Primary Education Only }(\text { ISCED }=1) \\
\quad(\text { mean }=0.37)\end{array}$ & $\begin{array}{c}0.0151 \\
(0.0238)\end{array}$ & $\begin{array}{c}0.0021 \\
(0.0348)\end{array}$ & 0.5927 \\
\hline $\begin{array}{l}\text { Has No Reported Annual Income } \\
\quad(\text { mean }=0.37)\end{array}$ & $\begin{array}{c}0.0687 * * * \\
(0.0175)\end{array}$ & $\begin{array}{l}0.0382 * \\
(0.0207)\end{array}$ & $0.0838 *$ \\
\hline $\begin{array}{l}\text { Annual Real Income }>12954 \\
\quad(\text { mean }=0.33)\end{array}$ & $\begin{array}{l}-0.0345^{* *} \\
(0.0163)\end{array}$ & $\begin{array}{l}-0.0081 \\
(0.0221)\end{array}$ & 0.1275 \\
\hline $\begin{array}{l}\text { Annual Real Income (pounds) } \\
(\text { mean }=10642.73)\end{array}$ & $\begin{array}{l}-789.36 \\
(523.54)\end{array}$ & $\begin{array}{l}-951.78 \\
(823.36)\end{array}$ & 0.798 \\
\hline $\begin{array}{l}\text { Owns Home } \\
\qquad(\text { mean }=0.83)\end{array}$ & $\begin{array}{l}-0.0318 \\
(0.0202)\end{array}$ & $\begin{array}{c}0.0060 \\
(0.0249)\end{array}$ & $0.0330 * *$ \\
\hline
\end{tabular}

Notes. Each row represents a separate regression. The sample sizes for each outcome correspond to the number of observations listed in Table 2. We interact standardized infant mortality with indicators for if your father worked in a lower or higher SES occupation when you were 14. We include the main effect of "High SES Occupation." The main effect of standardized infant mortality is subsumed by the interactions. All regressions control for fixed effects for district, year, and month of birth. Additional controls include dummies for current age, sex, and current region of residence, and birth rates which vary by district and cohort of birth. Standard errors clustered by district of birth are in parentheses. $* \mathrm{p}<0.10, * * \mathrm{p}<0.05, * * * \mathrm{p}<0.01$ 


\section{Table 5}

Relationship between Infant Mortality and Adult Health and Socioeconomic Status By Age

\begin{tabular}{|c|c|c|c|}
\hline & $\begin{array}{c}(1) \\
\text { Ages } \\
40-53\end{array}$ & $\begin{array}{c}(2) \\
\text { Ages } \\
54-59\end{array}$ & $\begin{array}{c}(3) \\
\text { Ages } \\
60-73\end{array}$ \\
\hline $\begin{array}{l}\text { Very Good/Excellent Health } \\
\quad(\text { mean }=0.68)\end{array}$ & $\begin{array}{l}-0.0049 \\
(0.0187)\end{array}$ & $\begin{array}{l}-0.0213 \\
(0.0171)\end{array}$ & $\begin{array}{l}-0.0240 \\
(0.0190)\end{array}$ \\
\hline $\begin{array}{l}\text { Poor/Very Poor Health } \\
\quad(\text { mean }=0.12)\end{array}$ & $\begin{array}{c}0.0153 \\
(0.0149)\end{array}$ & $\begin{array}{c}0.0380 * * * \\
(0.0134)\end{array}$ & $\begin{array}{c}0.0288 * * \\
(0.0138)\end{array}$ \\
\hline $\begin{array}{l}\text { Has Recent IP Visits } \\
\quad(\text { mean }=0.09)\end{array}$ & $\begin{array}{c}0.0025 \\
(0.0065)\end{array}$ & $\begin{array}{c}0.0067 \\
(0.0063)\end{array}$ & $\begin{array}{c}0.0065 \\
(0.0077)\end{array}$ \\
\hline $\begin{array}{l}\text { Has Reported Health Problems } \\
\quad(\text { mean }=0.69)\end{array}$ & $\begin{array}{c}0.0111 \\
(0.0204)\end{array}$ & $\begin{array}{c}0.0196 \\
(0.0190)\end{array}$ & $\begin{array}{c}0.0122 \\
(0.0181)\end{array}$ \\
\hline $\begin{array}{l}\text { Has Arm } / \mathrm{Leg} / \text { Hand Problem } \\
\quad(\text { mean }=0.38)\end{array}$ & $\begin{array}{c}0.0096 \\
(0.0207)\end{array}$ & $\begin{array}{c}0.0267 \\
(0.0186)\end{array}$ & $\begin{array}{c}0.0268 \\
(0.0204)\end{array}$ \\
\hline $\begin{array}{l}\text { Has Chest/Breathing Problem } \\
\quad(\text { mean }=0.13)\end{array}$ & $\begin{array}{c}0.0177 \\
(0.0179)\end{array}$ & $\begin{array}{r}0.0313^{* *} \\
(0.0155)\end{array}$ & $\begin{array}{r}0.0413 * * \\
(0.0160)\end{array}$ \\
\hline $\begin{array}{l}\text { Has Heart/BP Problem } \\
\quad(\text { mean }=0.23)\end{array}$ & $\begin{array}{l}-0.0071 \\
(0.0167)\end{array}$ & $\begin{array}{l}-0.0021 \\
(0.0157)\end{array}$ & $\begin{array}{c}0.0014 \\
(0.0169)\end{array}$ \\
\hline $\begin{array}{l}\text { Disabled } \\
\qquad(\text { mean }=0.10)\end{array}$ & $\begin{array}{l}0.0196^{*} \\
(0.0108)\end{array}$ & $\begin{array}{c}0.0316^{* * *} \\
(0.0111)\end{array}$ & $\begin{array}{c}0.0442 * * * \\
(0.0125)\end{array}$ \\
\hline $\begin{array}{l}\text { Has a Job at time of survey } \\
\quad(\text { mean }=0.56)\end{array}$ & $\begin{array}{l}-0.0296 \\
(0.0189)\end{array}$ & $\begin{array}{c}-0.0616^{* * *} \\
(0.0179)\end{array}$ & $\begin{array}{c}-0.0672^{* * *} \\
(0.0165)\end{array}$ \\
\hline $\begin{array}{l}\text { Primary Education Only }(\text { ISCED }=1) \\
\quad(\text { mean }=0.37)\end{array}$ & $\begin{array}{c}0.0216 \\
(0.0273)\end{array}$ & $\begin{array}{c}0.0383 \\
(0.0294)\end{array}$ & $\begin{array}{l}-0.0034 \\
(0.0292)\end{array}$ \\
\hline $\begin{array}{l}\text { Has No Reported Annual Income } \\
\quad(\text { mean }=0.37)\end{array}$ & $\begin{array}{c}0.0310 \\
(0.0190)\end{array}$ & $\begin{array}{c}0.0669 * * * \\
(0.0184)\end{array}$ & $\begin{array}{c}0.0765^{* * * *} \\
(0.0182)\end{array}$ \\
\hline $\begin{array}{l}\text { Annual Real Income }>12954 \\
\quad(\text { mean }=0.33)\end{array}$ & $\begin{array}{l}-0.0101 \\
(0.0189)\end{array}$ & $\begin{array}{c}-0.0401^{* *} \\
(0.0174)\end{array}$ & $\begin{array}{c}-0.0352^{* *} \\
(0.0160)\end{array}$ \\
\hline $\begin{array}{l}\text { Annual Real Income (pounds) } \\
\quad(\text { mean }=10642.73)\end{array}$ & $\begin{array}{l}-278.66 \\
(632.72))\end{array}$ & $\begin{array}{r}-1013.27^{*} \\
(572.06))\end{array}$ & $\begin{array}{l}-1033.27^{* *} \\
(523.24)\end{array}$ \\
\hline $\begin{array}{l}\text { Owns Home } \\
(\text { mean }=0.83)\end{array}$ & $\begin{array}{l}-0.0156 \\
(0.0215) \\
\end{array}$ & $\begin{array}{l}-0.0277 \\
(0.0202)\end{array}$ & $\begin{array}{l}-0.0312 \\
(0.0204)\end{array}$ \\
\hline
\end{tabular}

Notes. Each row represents a separate regression. The sample sizes for each outcome correspond to the number of observations listed in Table 2. We interact standardized infant mortality with terciles of age. All regressions control for fixed effects for district, year, and month of birth. Additional controls include dummies for current age, sex, and current region of residence, and birth rates which vary by district and cohort of birth. Standard errors clustered by district of birth are in parentheses. $* \mathrm{p}<0.10, * * \mathrm{p}<0.05, * * *$ $\mathrm{p}<0.01$ 
Table 6

Sensitivity Analyses

\begin{tabular}{|c|c|c|c|c|c|c|c|}
\hline & $\begin{array}{c}(1) \\
\text { Original } \\
\text { Estimates }\end{array}$ & $\begin{array}{c}(2) \\
\text { Cohorts } \\
1940 \text { to } \\
1950\end{array}$ & $\begin{array}{c}(3) \\
\text { Cohorts } \\
1935 \text { to } \\
1945\end{array}$ & $\begin{array}{c}(4) \\
\text { Cohorts } \\
1935 \text { to } \\
1955\end{array}$ & $\begin{array}{c}(5) \\
\text { Random } \\
\text { Wave per } \\
\text { person }\end{array}$ & $\begin{array}{c}(6) \\
\text { Only } \\
\text { variation in } \\
1940 / 41\end{array}$ & $\begin{array}{c}(7) \\
\text { Drop } \\
\text { London }\end{array}$ \\
\hline $\begin{array}{l}\text { Very Good/Excellent Health } \\
\quad(\text { mean }=0.68)\end{array}$ & $\begin{array}{l}-0.0190 \\
(0.0174)\end{array}$ & $\begin{array}{c}0.0048 \\
(0.0197)\end{array}$ & $\begin{array}{l}-0.0098 \\
(0.0214)\end{array}$ & $\begin{array}{l}-0.0262 * \\
(0.0148)\end{array}$ & $\begin{array}{l}-0.0241 \\
(0.0221)\end{array}$ & $\begin{array}{c}0.0172 \\
(0.0207)\end{array}$ & $\begin{array}{l}-0.0143 \\
(0.0189)\end{array}$ \\
\hline $\begin{array}{l}\text { Poor/Very Poor Health } \\
\quad(\text { mean }=0.12)\end{array}$ & $\begin{array}{c}0.0290 * * \\
(0.0131)\end{array}$ & $\begin{array}{c}0.0191 \\
(0.0154)\end{array}$ & $\begin{array}{c}0.0145 \\
(0.0152)\end{array}$ & $\begin{array}{c}0.0317 * * * \\
(0.0120)\end{array}$ & $\begin{array}{c}0.0291 \\
(0.0214)\end{array}$ & $\begin{array}{c}0.0053 \\
(0.0132)\end{array}$ & $\begin{array}{l}0.0254^{*} \\
(0.0140)\end{array}$ \\
\hline $\begin{array}{l}\text { Has Recent IP Visits } \\
\quad(\text { mean }=0.09)\end{array}$ & $\begin{array}{c}0.0057 \\
(0.0063)\end{array}$ & $\begin{array}{c}0.0069 \\
(0.0073)\end{array}$ & $\begin{array}{c}0.0005 \\
(0.0072)\end{array}$ & $\begin{array}{c}0.0055 \\
(0.0055)\end{array}$ & $\begin{array}{c}0.0214 \\
(0.0185)\end{array}$ & $\begin{array}{c}0.0004 \\
(0.0065)\end{array}$ & $\begin{array}{c}0.0044 \\
(0.0069)\end{array}$ \\
\hline $\begin{array}{l}\text { Has Reported Health Problems } \\
\quad(\text { mean }=0.69)\end{array}$ & $\begin{array}{c}0.0145 \\
(0.0178)\end{array}$ & $\begin{array}{c}0.0089 \\
(0.0223)\end{array}$ & $\begin{array}{c}0.0103 \\
(0.0192)\end{array}$ & $\begin{array}{c}0.0119 \\
(0.0146)\end{array}$ & $\begin{array}{c}0.0136 \\
(0.0233)\end{array}$ & $\begin{array}{l}-0.0084 \\
(0.0254)\end{array}$ & $\begin{array}{c}0.0052 \\
(0.0191)\end{array}$ \\
\hline $\begin{array}{l}\text { Has Arm } / \mathrm{Leg} / \text { Hand Problem } \\
\quad(\text { mean }=0.38)\end{array}$ & $\begin{array}{c}0.0232 \\
(0.0189)\end{array}$ & $\begin{array}{c}0.0274 \\
(0.0213)\end{array}$ & $\begin{array}{c}0.0115 \\
(0.0264)\end{array}$ & $\begin{array}{l}0.0287 * \\
(0.0158)\end{array}$ & $\begin{array}{c}0.0036 \\
(0.0257)\end{array}$ & $\begin{array}{l}-0.0150 \\
(0.0207)\end{array}$ & $\begin{array}{c}0.0199 \\
(0.0205)\end{array}$ \\
\hline $\begin{array}{l}\text { Has Chest/Breathing Problem } \\
\quad(\text { mean }=0.13)\end{array}$ & $\begin{array}{c}0.0330 * * \\
(0.0154)\end{array}$ & $\begin{array}{c}0.0204 \\
(0.0162)\end{array}$ & $\begin{array}{c}0.0276 \\
(0.0179)\end{array}$ & $\begin{array}{c}0.0402 * * * \\
(0.0130)\end{array}$ & $\begin{array}{l}0.0346 * \\
(0.0183)\end{array}$ & $\begin{array}{c}0.0079 \\
(0.0188)\end{array}$ & $\begin{array}{c}0.0232 \\
(0.0159)\end{array}$ \\
\hline $\begin{array}{l}\text { Has Heart/BP Problem } \\
\quad(\text { mean }=0.23)\end{array}$ & $\begin{array}{l}-0.0016 \\
(0.0153)\end{array}$ & $\begin{array}{c}0.0045 \\
(0.0175)\end{array}$ & $\begin{array}{l}-0.0021 \\
(0.0194)\end{array}$ & $\begin{array}{l}-0.0004 \\
(0.0133)\end{array}$ & $\begin{array}{c}0.0076 \\
(0.0219)\end{array}$ & $\begin{array}{c}0.0071 \\
(0.0225)\end{array}$ & $\begin{array}{l}-0.0053 \\
(0.0161)\end{array}$ \\
\hline $\begin{array}{l}\text { Disabled } \\
\qquad(\text { mean }=0.10)\end{array}$ & $\begin{array}{c}0.0348 * * * \\
(0.0110)\end{array}$ & $\begin{array}{l}0.0329 * * * \\
(0.0124)\end{array}$ & $\begin{array}{c}0.0357 * * \\
(0.0143)\end{array}$ & $\begin{array}{c}0.0376^{* * * *} \\
(0.0098)\end{array}$ & $\begin{array}{c}0.0398 * * \\
(0.0174)\end{array}$ & $\begin{array}{l}0.0200 * \\
(0.0117)\end{array}$ & $\begin{array}{c}0.0309 * * * \\
(0.0118)\end{array}$ \\
\hline $\begin{array}{l}\text { Has a Job at time of Survey } \\
\quad(\text { mean }=0.56)\end{array}$ & $\begin{array}{c}-0.0574 * * * \\
(0.0163)\end{array}$ & $\begin{array}{c}-0.0489 * * * \\
(0.0188)\end{array}$ & $\begin{array}{c}-0.0572 * * * \\
(0.0186)\end{array}$ & $\begin{array}{c}-0.0520 * * * \\
(0.0143)\end{array}$ & $\begin{array}{l}-0.0295 \\
(0.0221)\end{array}$ & $\begin{array}{c}-0.0475 * * * \\
(0.0166)\end{array}$ & $\begin{array}{c}-0.0572 * * * \\
(0.0174)\end{array}$ \\
\hline $\begin{array}{l}\text { College or Higher }(\text { ISCED }=5 a \\
\text { or } 6 \text { ) }\end{array}$ & 0.0210 & 0.0197 & 0.0084 & 0.0197 & 0.0210 & 0.0146 & 0.0220 \\
\hline$($ mean $=0.08)$ & $(0.0241)$ & $(0.0280)$ & $(0.0248)$ & $(0.0194)$ & $(0.0241)$ & $(0.0303)$ & $(0.0251)$ \\
\hline
\end{tabular}




\begin{tabular}{|c|c|c|c|c|c|c|c|}
\hline $\begin{array}{l}\text { Has No Reported Annual Income } \\
\quad(\text { mean }=0.37)\end{array}$ & $\begin{array}{c}0.0638 * * * \\
(0.0171)\end{array}$ & $\begin{array}{c}0.0533 * * * \\
(0.0196)\end{array}$ & $\begin{array}{c}0.0580 * * * \\
(0.0201)\end{array}$ & $\begin{array}{c}0.0606 * * * \\
(0.0147)\end{array}$ & $\begin{array}{l}0.0394 * \\
(0.0216)\end{array}$ & $\begin{array}{c}0.0578 * * * \\
(0.0181)\end{array}$ & $\begin{array}{r}0.0623 * * * \\
(0.0181)\end{array}$ \\
\hline $\begin{array}{l}\text { Annual Real Income }>12954 \\
\quad(\text { mean }=0.33)\end{array}$ & $\begin{array}{l}-0.0317 * \\
(0.0161)\end{array}$ & $\begin{array}{l}-0.0310 \\
(0.0191)\end{array}$ & $\begin{array}{l}-0.0178 \\
(0.0187)\end{array}$ & $\begin{array}{l}-0.0176 \\
(0.0147)\end{array}$ & $\begin{array}{l}-0.0116 \\
(0.0216)\end{array}$ & $\begin{array}{l}-0.0222 \\
(0.0178)\end{array}$ & $\begin{array}{l}-0.0262 \\
(0.0165)\end{array}$ \\
\hline $\begin{array}{l}\text { Annual Real Income (pounds) } \\
\quad(\text { mean }=10642.73)\end{array}$ & $\begin{array}{l}-869.76 \\
(529.55)\end{array}$ & $\begin{array}{l}-1038.80 \\
(662.35)\end{array}$ & $\begin{array}{l}-172.02 \\
(590.25)\end{array}$ & $\begin{array}{c}-1261.92 * * \\
(500.74)\end{array}$ & $\begin{array}{c}-189.24 \\
(652.13))\end{array}$ & $\begin{array}{l}-789.02 \\
(565.07)\end{array}$ & $\begin{array}{l}-719.50 \\
(526.90)\end{array}$ \\
\hline $\begin{array}{l}\text { Owns Home } \\
\quad(\text { mean }=0.83)\end{array}$ & $\begin{array}{l}-0.0267 \\
(0.0196)\end{array}$ & $\begin{array}{l}-0.0218 \\
(0.0243)\end{array}$ & $\begin{array}{l}-0.0078 \\
(0.0193)\end{array}$ & $\begin{array}{l}-0.0245 \\
(0.0159)\end{array}$ & $\begin{array}{l}-0.0451^{*} \\
(0.0234)\end{array}$ & $\begin{array}{l}-0.0266 \\
(0.0209)\end{array}$ & $\begin{array}{l}-0.0310 \\
(0.0214)\end{array}$ \\
\hline
\end{tabular}




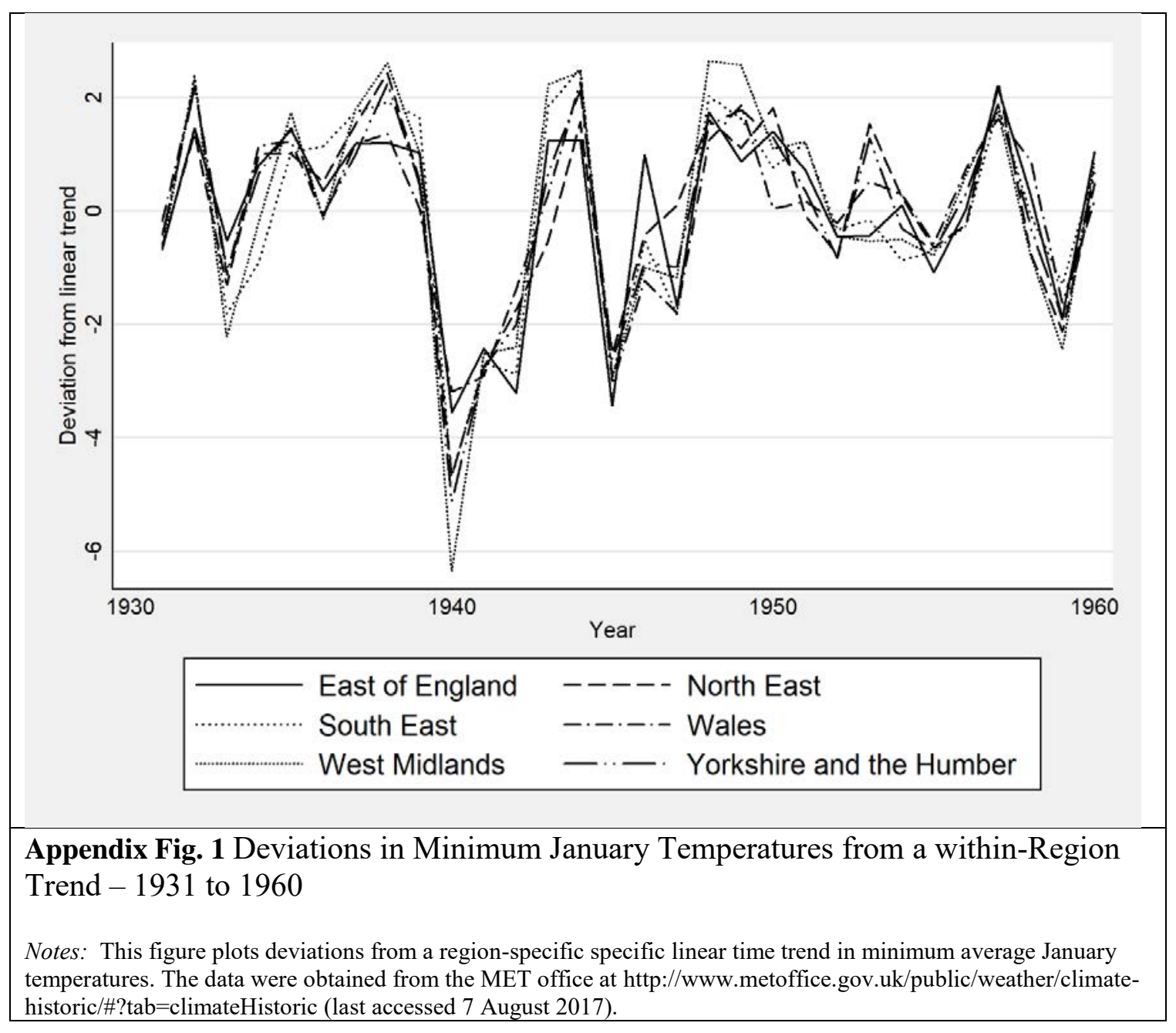




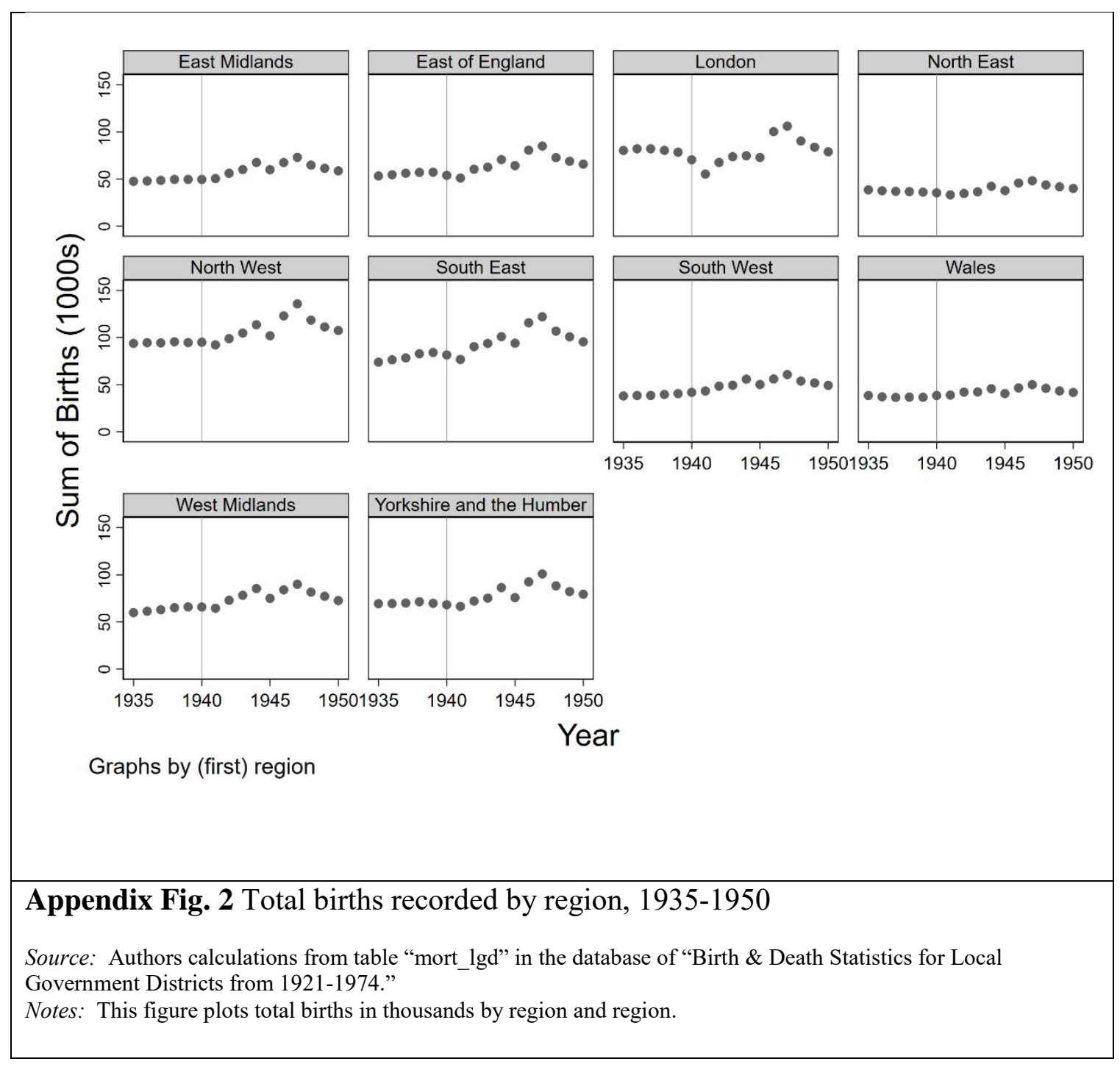




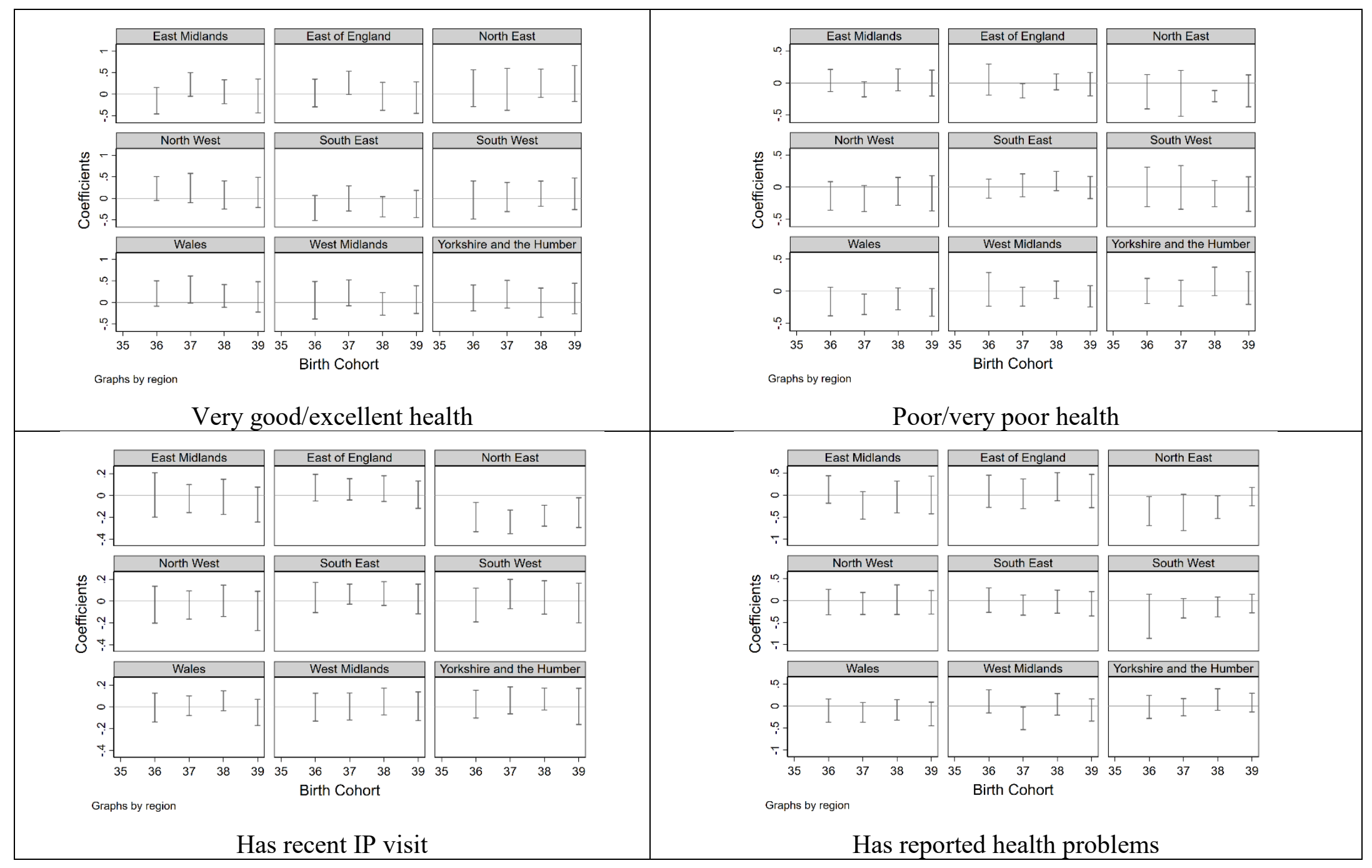




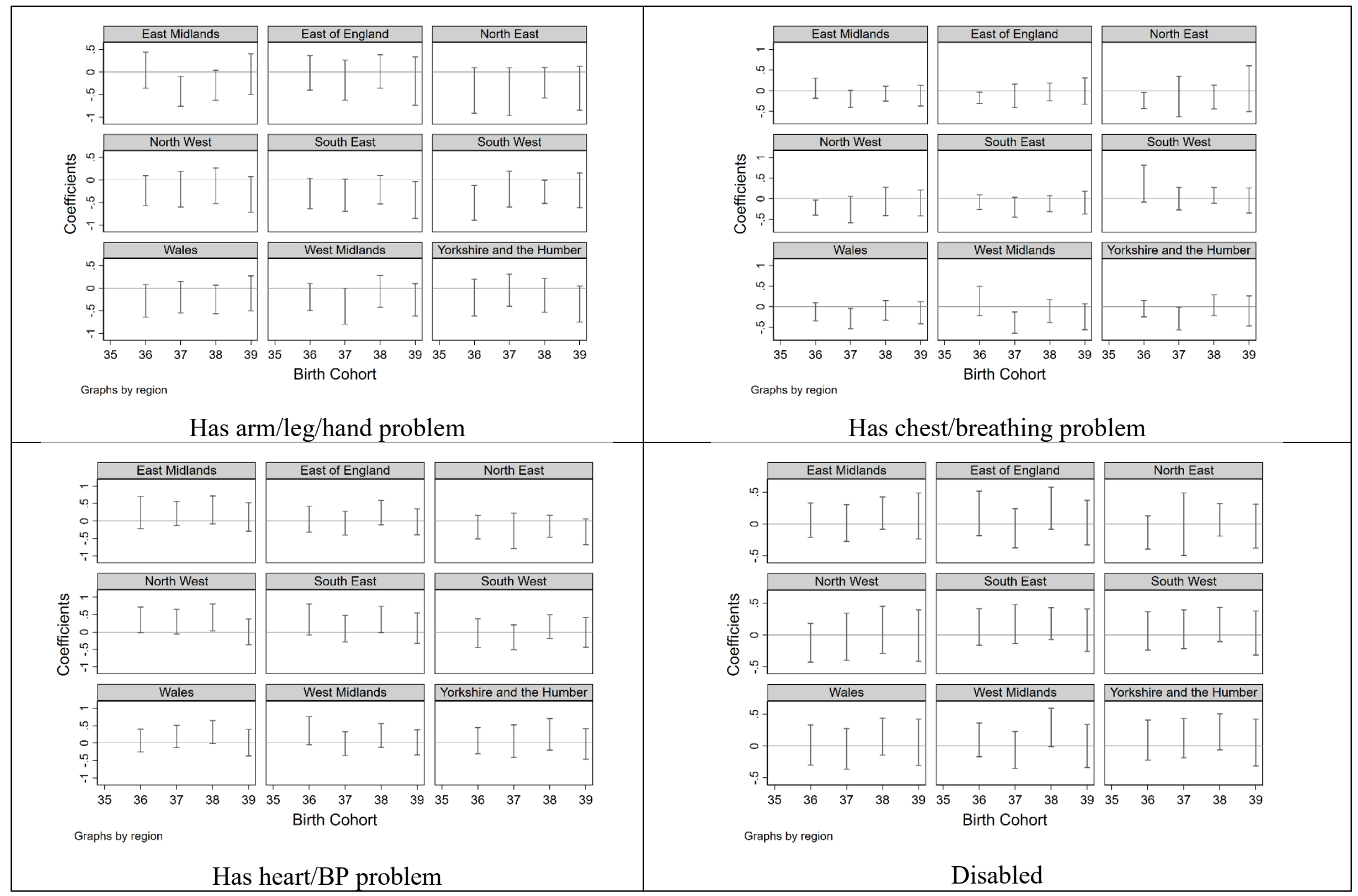




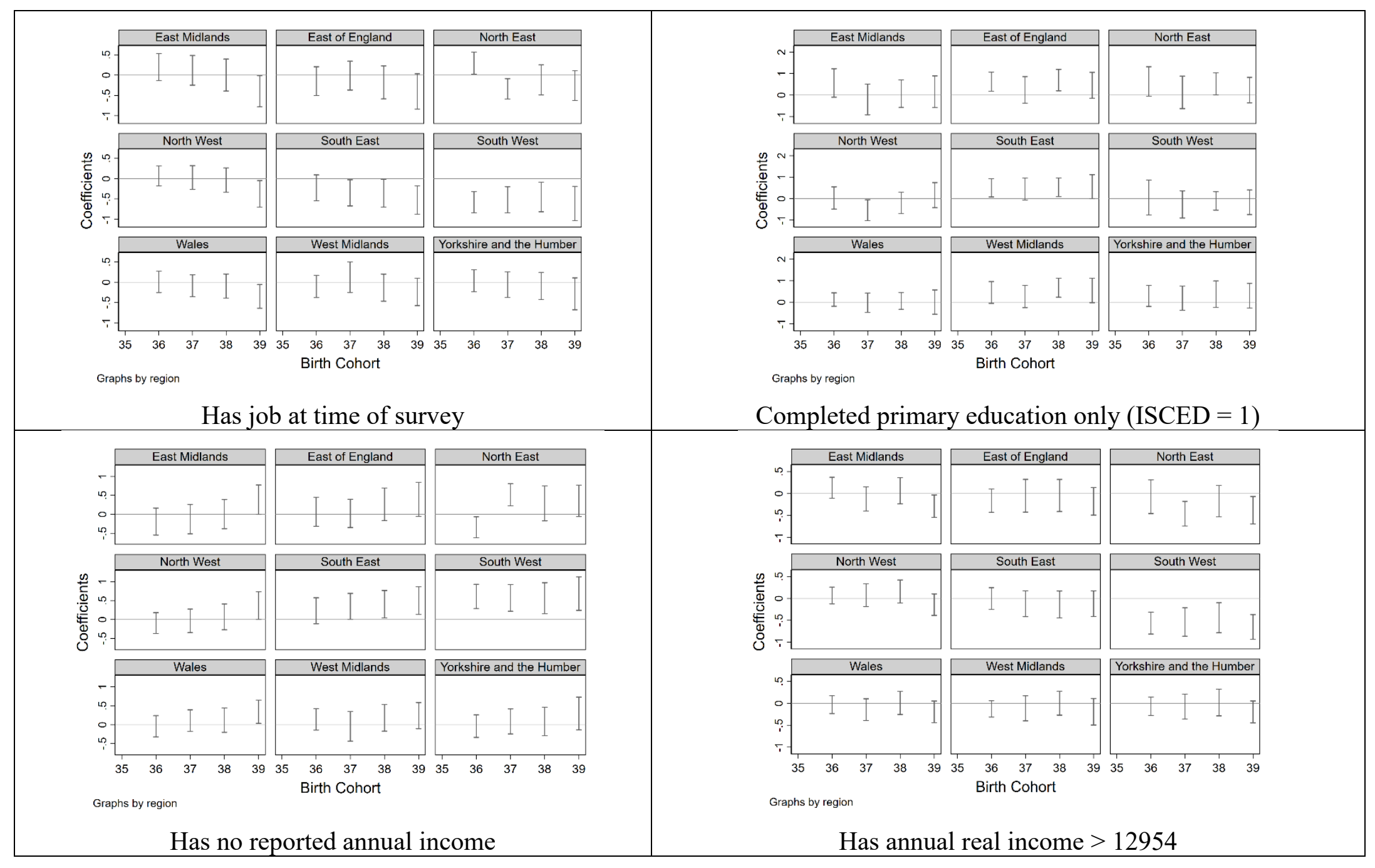




Appendix Fig. 3 Evidence of Parallel Pre-trends in Outcomes
Notes. The above figures are results of a regression analysis using each outcome as a function of region fixed effects, cohort fixed effects, and region-
by-cohort fixed effects. We omit London as the base region and 1935 as the base cohort and cluster standard errors by district. The coefficients are from
the region-by-cohort fixed effects.




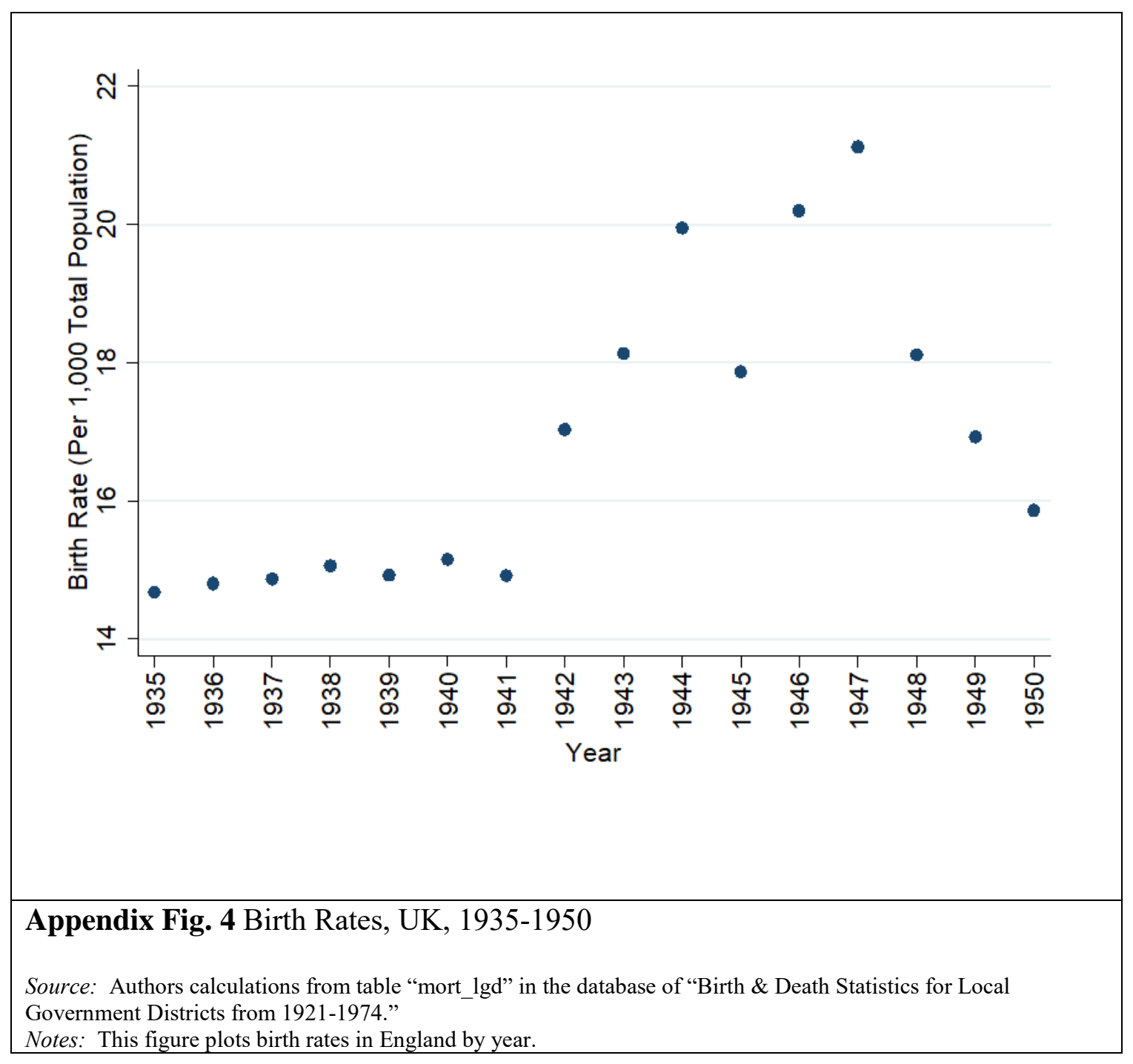




\section{Appendix Table 1}

Descriptive Statistics Before and After Dropping, Mean (SD)

\begin{tabular}{|c|c|c|c|c|}
\hline & $\begin{array}{c}\text { Initial } \\
\text { Sample } \\
\end{array}$ & $\begin{array}{c}\text { After Dropping } \\
\text { Observations Missing } \\
\text { Place of Birth } \\
\end{array}$ & $\begin{array}{c}\text { Analysis } \\
\text { Sample }\end{array}$ & $\begin{array}{l}\text { R-Square from } \\
\text { regression of } \\
\text { outcome on in final } \\
\text { sample indicator }\end{array}$ \\
\hline Good or Excellent Self-Reported Health & $\begin{array}{c}0.662 \\
(0.473)\end{array}$ & $\begin{array}{c}0.666 \\
(0.472)\end{array}$ & $\begin{array}{c}0.678 \\
(0.467)\end{array}$ & 0.0022 \\
\hline Poor or Very Poor Health & $\begin{array}{c}0.128 \\
(0.334)\end{array}$ & $\begin{array}{c}0.126 \\
(0.332)\end{array}$ & $\begin{array}{c}0.120 \\
(0.325)\end{array}$ & 0.0011 \\
\hline Has Recent Inpatient Visits & $\begin{array}{c}0.097 \\
(0.296)\end{array}$ & $\begin{array}{c}0.096 \\
(0.294)\end{array}$ & $\begin{array}{c}0.093 \\
(0.290)\end{array}$ & 0.0005 \\
\hline Has Reported Health Problems & $\begin{array}{c}0.698 \\
(0.459)\end{array}$ & $\begin{array}{c}0.699 \\
(0.459)\end{array}$ & $\begin{array}{c}0.694 \\
(0.461)\end{array}$ & 0.0001 \\
\hline Has Arm/Leg/Hand Problem & $\begin{array}{c}0.378 \\
(0.485)\end{array}$ & $\begin{array}{c}0.380 \\
(0.485)\end{array}$ & $\begin{array}{c}0.381 \\
(0.486)\end{array}$ & 0.0001 \\
\hline Has Chest/Breathing Problem & $\begin{array}{c}0.132 \\
(0.339)\end{array}$ & $\begin{array}{c}0.132 \\
(0.339)\end{array}$ & $\begin{array}{c}0.129 \\
(0.336)\end{array}$ & 0.0001 \\
\hline Has Heart/BP Problem & $\begin{array}{c}0.251 \\
(0.434)\end{array}$ & $\begin{array}{c}0.250 \\
(0.433)\end{array}$ & $\begin{array}{c}0.233 \\
(0.423)\end{array}$ & 0.0034 \\
\hline Disabled & $\begin{array}{c}0.110 \\
(0.313)\end{array}$ & $\begin{array}{c}0.109 \\
(0.311)\end{array}$ & $\begin{array}{c}0.097 \\
(0.295)\end{array}$ & 0.0038 \\
\hline Completed Only Primary Education & $\begin{array}{c}0.354 \\
(0.478)\end{array}$ & $\begin{array}{c}0.354 \\
(0.478)\end{array}$ & $\begin{array}{c}0.341 \\
(0.474)\end{array}$ & 0.0015 \\
\hline Has a Job at time of survey & $\begin{array}{c}0.526 \\
(0.499)\end{array}$ & $\begin{array}{c}0.538 \\
(0.499)\end{array}$ & $\begin{array}{c}0.559 \\
(0.497)\end{array}$ & 0.0085 \\
\hline Annual Income & $\begin{array}{c}8383.57 \\
(12734.12)\end{array}$ & $\begin{array}{c}8361.10 \\
(12755.15)\end{array}$ & $\begin{array}{c}8889.42 \\
(12891.38)\end{array}$ & 0.0032 \\
\hline Owns Home & $\begin{array}{c}0.805 \\
(0.397)\end{array}$ & $\begin{array}{c}0.806 \\
(0.396)\end{array}$ & $\begin{array}{c}0.825 \\
(0.380)\end{array}$ & 0.0053 \\
\hline Female & $\begin{array}{c}0.536 \\
(0.536)\end{array}$ & $\begin{array}{c}0.538 \\
(0.499)\end{array}$ & $\begin{array}{c}0.535 \\
(0.535)\end{array}$ & 0.0000 \\
\hline Age & $\begin{array}{l}56.77 \\
(6.74)\end{array}$ & $\begin{array}{l}56.71 \\
(6.75)\end{array}$ & $\begin{array}{l}55.97 \\
(6.78)\end{array}$ & 0.0275 \\
\hline Birth Year & $\begin{array}{l}1943.3 \\
(4.49)\end{array}$ & $\begin{array}{l}1943.3 \\
(4.47)\end{array}$ & $\begin{array}{l}1943.4 \\
(4.45)\end{array}$ & 0.0011 \\
\hline Birth Month & $\begin{array}{c}6.49 \\
(3.43)\end{array}$ & $\begin{array}{c}6.49 \\
(3.42)\end{array}$ & $\begin{array}{c}6.52 \\
(3.42)\end{array}$ & 0.0001 \\
\hline
\end{tabular}


Appendix Table 2

Relationship between Infant Mortality Measured at the District-Cohort Level and Adult Health and Socioeconomic Status

\begin{tabular}{|c|c|c|}
\hline & $(1)$ & $(2)$ \\
\hline $\begin{array}{l}\text { Very Good/Excellent Health } \\
\quad(\text { mean }=0.68)\end{array}$ & $\begin{array}{l}-0.0190 \\
(0.0174)\end{array}$ & $\begin{array}{l}-0.0190 \\
(0.0170)\end{array}$ \\
\hline $\begin{array}{l}\text { Poor/Very Poor Health } \\
\quad(\text { mean }=0.12)\end{array}$ & $\begin{array}{c}0.0290 * * \\
(0.0131)\end{array}$ & $\begin{array}{c}0.0290 * * \\
(0.0121)\end{array}$ \\
\hline $\begin{array}{l}\text { Has Recent IP Visits } \\
\quad(\text { mean }=0.09)\end{array}$ & $\begin{array}{c}0.0057 \\
(0.0063)\end{array}$ & $\begin{array}{c}0.0057 \\
(0.0066)\end{array}$ \\
\hline $\begin{array}{l}\text { Has Reported Health Problems } \\
\quad(\text { mean }=0.69)\end{array}$ & $\begin{array}{c}0.0145 \\
(0.0178)\end{array}$ & $\begin{array}{c}0.0145 \\
(0.0164)\end{array}$ \\
\hline $\begin{array}{l}\text { Has Arm } / \mathrm{Leg} / \text { Hand Problem } \\
\quad(\text { mean }=0.38)\end{array}$ & $\begin{array}{c}0.0232 \\
(0.0189)\end{array}$ & $\begin{array}{c}0.0232 \\
(0.0178)\end{array}$ \\
\hline $\begin{array}{l}\text { Has Chest/Breathing Problem } \\
\quad(\text { mean }=0.13)\end{array}$ & $\begin{array}{r}0.0330 * * \\
(0.0154)\end{array}$ & $\begin{array}{c}0.0330 * * \\
(0.0143)\end{array}$ \\
\hline $\begin{array}{l}\text { Has Heart/BP Problem } \\
\quad(\text { mean }=0.23)\end{array}$ & $\begin{array}{l}-0.0016 \\
(0.0153)\end{array}$ & $\begin{array}{l}-0.0016 \\
(0.0161)\end{array}$ \\
\hline $\begin{array}{l}\text { Disabled } \\
\quad(\text { mean }=0.10)\end{array}$ & $\begin{array}{c}0.0348 * * * \\
(0.0110)\end{array}$ & $\begin{array}{c}0.0348 * * * \\
(0.0113)\end{array}$ \\
\hline $\begin{array}{l}\text { Has a Job at time of survey } \\
\quad(\text { mean }=0.56)\end{array}$ & $\begin{array}{l}-0.0574 * * * \\
(0.0163)\end{array}$ & $\begin{array}{l}-0.0574 * * * \\
\quad(0.0158)\end{array}$ \\
\hline $\begin{array}{l}\text { College or Higher }(\text { ISCED }=5 \mathrm{a} \text { or } 6) \\
\quad(\text { mean }=0.08)\end{array}$ & $\begin{array}{c}0.0137 \\
(0.0123)\end{array}$ & $\begin{array}{c}0.0137 \\
(0.0131)\end{array}$ \\
\hline $\begin{array}{l}\text { Has No Reported Annual Income } \\
\quad(\text { mean }=0.37)\end{array}$ & $\begin{array}{c}0.0638 * * * \\
(0.0171)\end{array}$ & $\begin{array}{c}0.0638 * * * \\
(0.0167)\end{array}$ \\
\hline $\begin{array}{l}\text { Annual Real Income }>12954 \\
\quad(\text { mean }=0.33)\end{array}$ & $\begin{array}{l}-0.0317 * \\
(0.0161)\end{array}$ & $\begin{array}{c}-0.0317 * * \\
(0.0154)\end{array}$ \\
\hline $\begin{array}{l}\text { Annual Real Income (pounds) } \\
(\text { mean }=10642.73)\end{array}$ & $\begin{array}{l}-869.76 \\
(529.55)\end{array}$ & $\begin{array}{l}-869.76^{*} \\
(504.08)\end{array}$ \\
\hline $\begin{array}{l}\text { Owns Home } \\
\quad(\text { mean }=0.83)\end{array}$ & $\begin{array}{l}-0.0267 \\
(0.0196)\end{array}$ & $\begin{array}{l}-0.0267 \\
(0.0174)\end{array}$ \\
\hline Level of clustering for the standard errors & District & Person \\
\hline \multicolumn{3}{|c|}{$\begin{array}{l}\text { Notes. Each estimate comes from a separate regression. The sample sizes for each } \\
\text { outcome correspond to the number of observations listed in Table } 2 \text {. The key } \\
\text { independent variable, infant mortality, is standardized to be mean } 0 \text { and standard } \\
\text { deviation } 1 \text {. All regressions control for fixed effects for district, cohort, month of birth, } \\
\text { dummies for current age, sex, and current region of residence, and birth rates. Column } \\
1 \text { corresponds to column } 3 \text { of Table } 3 \text {, where standard errors are clustered by district. }\end{array}$} \\
\hline
\end{tabular}


In column 2 , we cluster the standard errors by person. $* \mathrm{p}<0.10, * * \mathrm{p}<0.05, * * *$ $\mathrm{p}<0.01$ 